\title{
Adaptation Strategies of Multinational Corporations, State-Owned Enterprises, and Domestic Business Groups to Economic and Political Transitions: A Network Analysis of the Chilean Telecommunications Sector, 1958-2005
}

\author{
Marcelo Bucheli and Erica Salvaj
}

Note:

This paper has been published in Enterprise and Society 15: 534-576. If you want to cite it, please refer to that publicaction.

https://muse.jhu.edu/journals/enterprise_and_society/toc/ens.15.3.html 
Adaptation Strategies of Multinational Corporations, State-Owned Enterprises, and Domestic Business Groups to Economic and Political Transitions: A Network Analysis of the Chilean Telecommunications Sector, 1958- 2005

\author{
Marcelo Bucheli \\ Associate Professor \\ Department of Business Administration \\ University of Illinois at Urbana-Champaign \\ 350 Wohlers Hall \\ 1206 South Sixth Street, Champaign, IL 61820, USA \\ Email: mbucheli@illinois.edu \\ Phone: $1+$ (217) 244-0208 \\ Erica Salvaj \\ Professor \\ Facultad de Economía y Negocios \\ Universidad del Desarrollo \\ Av. Plaza 608 Las Condes \\ Santiago, Chile \\ Email: esalvaj@udd.cl \\ Phone: 56+28800052
}

\begin{abstract}
This paper compares the corporate network strategies between multinationals from a traditional capital exporting country (US), multinationals from a non-traditional capital exporting country (Spain), business groups, and state-owned enterprises in the public utility sector of a developing country during times of political and economic transition. Focusing on network strategies in the Chilean telecommunications sector through interlocking activities we find that while in times of protectionism US investors sought to create links with Chile's corporate sector in order to coordinate their activities, in times of an open economy Spanish investors created links with the government in order to legitimize their operations. We also find that state-owned companies did not attempt to build networks with other industries. Finally, we find that during a democratic regime all firms sought to build more networks
\end{abstract}


with each other, while during a dictatorial one the centralization of power in one individual decreased the incentives among firms to build networks with each other. 
The long-term story of the public utilities corporations in Latin America reflects the changing models of development adopted by domestic elites since the late nineteenth century. Aware that no country could overcome problems of poverty and underdevelopment without affordable and wide coverage of basic services such as telecommunications, transportation, water, sewage, or road construction the Latin American countries have experimented with different types of ownership of public utilities corporations ranging from completely foreign-owned corporations, concession grants to foreign or domestic investors, or state-owned enterprises. Each type of ownership resulted from wider economic models that reflected dominant philosophical approaches on what the role of the state and foreign capital in the economy should be. These economic models resulted from (often violent) political struggles between different groups defending their particular philosophical approaches, with some advocating for public utilities to be in hands of a state that provided coverage through social planning and others believing that market forces and private investors (either domestic or foreign) were the best option to guarantee large coverage and good service.

In this paper, we analyze how the politically and economically determined types of ownership (meaning domestic state, domestic firms or multinationals) affected the way a major public utility firm related with the rest of the economy. We understand the relationship of the firm with other actors as the links the particular utility corporation builds with other sectors of the economy through the presence of individuals sitting in the board of directors of other firms (or interlocking). We focus on the Chilean telecommunications sector between 1958 and 2000. During this period, Chilean telecommunications went through three types of ownership that also reflected the dominant economic philosophies of the country: a wholly owned subsidiary of the US multinational ITT (1958-1972), two state-owned enterprises (1972-1987 and 1969-1988), a company owned by Chilean business groups (1999-2005), a privatized firm jointly owned between foreign Italian investors and Chilean business groups (19871999), a privatized firm owned by an Australian investment group (1988-1990), and a company owned by the Spanish multinational Telefónica (1990-2005). During this period Chile also had a democratic regime (1958-1973 and 1990-present) and a military dictatorship (1973-1990).

We argue that different kinds of boards responded to different motivations of each of the main actors and were determined by the political and economic environment. For instance, while the US investors operating in times of democracy and protectionism sought to create links with other important Chilean firms in other sectors in order to coordinate their activities with these domestic actors, Spanish investors operating in the period after Chile transitioned from dictatorship to democracy built links with 
the center-left government in order to legitimize their operations and obtain protection against hostile actions. Regarding the domestic actors, we find that during the period of state ownership under the dictatorship, the government did not attempt to build links with other firms. We find something similar in the private sector, where firms did not attempt to create links with each other during the military regime. We argue that this responds to the very nature of the regime in which concentrated political power made informal links with the ruler more important than formal links with other firms. Regarding the domestic business groups operating in the post-transition democratic government, we find that they did not attempt to build links with the government (as the Spanish investors did). We argue that because of the nature of business groups, it made more sense for them to build links within the group in order to coordinate the group's activities, while relying in informal networks with the government.

The phases in type of ownership, economic policies, and political regimes in Chile are consistent with wider global and regional trends. After World War II, the world witnessed increasing protectionism and hostility towards free markets, while Latin America opted for a state-led import substitution industrialization model (ISI), ${ }^{1}$ a model that facilitated the rise or consolidation of domestic business groups. $^{2}$ Scholars studying the networks created between multinational corporations, business groups, and governments in Latin America during ISI in a historical perspective have attempted to understand why such networks were created. One group of scholars argues that during this period these three actors created an alliance and coordinated their operations with the purpose of building a business-friendly environment and creating a common front against labor unionism. ${ }^{3}$ Others add that the alliance was also necessary to dismantle ISI, something that would not have counted with the support of labor unions and some protected industrial sectors, ${ }^{4}$ a view shared by some scholars studying Chile. ${ }^{5}$ The more recent analysis by Ben Ross Schneider posit that they way the Latin American (and the Chilean) domestic sector organized itself and the types of connections domestic firms build with each other and with the state resulted from state-led initiatives by governments that needed to coordinate the ISI with the private

\footnotetext{
${ }^{1}$ Geoffrey Jones, Multinationals and Global Capitalism (Oxford, 2005), 16-41; Luis Bértola and José Antonio Ocampo, The Economic Development of Latin America(Oxford, 2012), 138-197.

${ }^{2}$ Ben Ross Schneider, Business Politics and the State in Twentieth-Century Latin America (Cambridge, 2004).

${ }^{3}$ Peter Evans, Dependent development: The alliance of multinational, state, and local capital in Brazil (Princeton, 1979); Guillermo O’Donnell, El estado burocrático autoritario: 1966-1973 (Buenos Aires, 1982).

${ }^{4}$ Peter Evans, Dependent development: The alliance of multinational, state, and local capital in Brazil (Princeton, 1979); Guillermo O’Donnell, El estado burocrático autoritario: 1966-1973 (Buenos Aires, 1982).

${ }^{5}$ Maurice Zeitlin, Linda Ewen, and Richard Radcliff, 'New Princes' for Old? The Large Corporation and the Capitalist Class in Chile,' American Journal of Sociology, 80, no. 1 (1974), 87-123; Maurice Zeitlin and Richard Radcliff, Landlords and Capitalists: The Dominant Class in Chile (Princeton, 1988).
} 
sector. $^{6}$ Scholars consider the Chilean business groups as one of the best representatives of this type of organizations world-wide and there is a consensus that they benefited from ISI and their close relationship with the government. ${ }^{7}$ The end of ISI forced these business groups to re-orient their activities towards global competition and markets, but they remained highly influential during the Pinochet regime. ${ }^{8}$ The adoption of free-market policies by Pinochet in Chile and by other Latin American countries in the 1980s and 1990s, opened the doors to new investors coming from nontraditional capital-exporting countries such as Spain, particularly in the public utilities sector. ${ }^{9}$

This paper contributes to the literature on the relationship between the state, business groups, and multinational corporations in Latin America by comparing its evolution between the ISI and open market periods and by comparing these relationships between authoritarian and democratic regimes. We contribute to the studies that claim that the transition from ISI to open markets required an alliance between foreign capital, state, and the domestic elite (represented by domestic business groups) by systematically studying through a historical network analysis whether such alliance existed, to what degree, and how it changed after the authoritarian regime ended.

We make a contribution to the literature with our methodological approach. Scholars on network analysis have pointed out that most studies still remain too a-historical and US-oriented and have made calls for more international and historically informed studies. ${ }^{10}$ We respond to recent calls in the field of

\footnotetext{
${ }^{6}$ Ben Ross Schneider, Business Politics and the State in Twentieth Century Latin America (Cambridge, 2004).

${ }^{7}$ Adolfo Ibáñez, Herido en el ala: estado, oligarquías y subesarrollo (Santiago, 2003); Michael Monteón, Chile and the Great Depression: The Politics of Underdevelopment, 1927-1948 (Tempe, 1998); Mats Lundahl, 'El camino a la dictadura: desarrollo político y económico en Chile, 1952-1973' in Roberto García (ed.), Economía y política durante el gobierno military en Chile, 1973-1987 (Mexico, 1989); Fernando Dahse, Mapa de la extrema riqueza: grupos económicos y el problema de concentración de capitales (Santiago, 1979); Schneider, Business Politics and the State in Twentieth-Century Latin America (Cambridge, 2004), 152-172; Luis Corvalán Marquéz, Del anticapitalismo al neoliberalismo en Chile: izquierda, centro y derecha en la lucha entre los proyectos globales, 1950-2000 (Santiago, 2001); Zeitlin, Ewen, and Radcliff, 'New Princes'; Zeitlin and Radcliff, Landlords.

${ }^{8}$ Eduardo Silva, The State and Capital in Chile: Business elites, technocrats, and market economics (Boulder, 1996); Eduardo Silva, "Capitalist Coalitions, the State, and Neoliberal Economic Restructuring in Chile, 1973-88," World Politics, 45, No. 4 (1993), 526-559; Patricio del Sol and Joseph Kogan, "Regional competitive advantage based on pioneering economic reforms: the case of Chilean FDI," Journal of International Business Studies, 38 (2007), 901-927; Tarun Khanna and Krishna Palepu, "Policy Shocks, Market Intermediaries, and Corporate Strategy: Evidence from Chile and India," Journal of Economics and Management Strategy, 8 (1999), 271-310; Tarun Khanna and Krishna Palepu, "The Future of Business Groups in Emerging Markets: Long-Run Evidence from Chile," Academy of Management Journal, 43 (2000), 268285; Geoffrey Jones and Andrea Lluch, 'Empresas y empresarios de Argentina y Chile en la segunda economía global,' in Geoffrey Jones and Andrea Lluch (eds.), El impacto histórico de la globalización en Argentina y Chile: empresas y empresarios (Buenos Aires, 2011), 261-268.

${ }^{9}$ Keith Salmon, "Spanish Foreign Investment, Transnationals, and the Redefinition of the Spanish Business Realm," International Journal of Iberian Studies, 14, No. 2 (2001), 95-109; Mauro Guillén, The Rise of Spanish Multinationals: European Business in the Global Economy (Cambridge, 2005).

${ }^{10}$ Mark S. Mizruchi and Christopher Marquis, "Interlocking Directorates," in Jens Beckert and Milan Zafirovski (eds.), International Encyclopedia of Economic Sociology (London: Routledge, 2006), 375-377.
} 
business history advocating for comparative studies that employ new methodologies, analyze the role of firms as the main actors in globalization, and try to understand the evolution over time of the relationship between states and firms. ${ }^{11}$ So far, the main business historical study utilizing network analysis for Latin America is the pioneer study by Aldo Musacchio and Ian Read comparing elite networks in Brazil and Mexico in the early twentieth century. ${ }^{12}$ Building on their contribution, our study has two important differences with respect to theirs. First, Musacchio and Read's article focuses on one particular year and does not engage in a longitudinal study. Second, their study does not specify which industries they analyze. By conducting a longitudinal study and looking carefully the particular corporations, our paper not only shows the type of networks existing between industries, but also shows their evolution with time in relation to the political and economic environment. ${ }^{13}$

We also contribute to the literature on the political economy of Spanish investments in Latin America. Up to date, scholars have focused on those firms' relations with the Spanish government ${ }^{14}$ and their expansion abroad in the context of Spain's entry to the European Economic Community. ${ }^{15}$ Works studying the history of Telefónica in Latin America do not consider political strategies. ${ }^{16}$

Finally, as we explain in our methodology section, the richness and level of detail of our unique database can provide scholars with research material for further studies on the evolution of the Chilean corporate sector and a model for studies in other countries.

\footnotetext{
${ }^{11}$ Walter Friedman and Geoffrey Jones, 'Business History: Time for Debate,' Business History Review, 85, No. 1 (2011), 18.

${ }^{12}$ Aldo Musacchio and Ian Read, 'Bankers, Industrialists, and their Cliques: Elite Networks in Mexico and Brazil During Early Industrialization,' Enterprise and Society, 8, No. 4 (2007), 842-880.

13 Recent scholarship has made important contributions to our understanding of the role of networks between firms in a historical perspective. A good example for the United States is Susie Pak, Gentlemen Bankers: The World of J. P. Morgan (Cambridge, 2013).
}

\footnotetext{
${ }^{14}$ José Manuel Campa and Mauro Guillén, 'Spain: a Boom from Economic Integration,' in John H. Dunning and Rajneesh Narula, Foreign Direct Investment and Governments: Catalysts for Economic Restructuring (London: Routledge, 1998), 161187; Mauro Guillén and Adrian Tschoegl, Building a Global Bank: The Transformation of Banco Santander (Princeton: Princeton University Press, 2008); Jesús Valdaliso, "Spanish Shipping Firms in the Twentieth Century: Between the Internalization of the Market and the Nationalism of the State," International Journal of Maritime History 19 (2007), 21-42; Guillén, The Rise.

${ }^{15}$ Salmon, "Spanish Foreign Direct Investment”; Borgoña Fuster García and Carmen Martínez Mora, "Internalización de la economía alicantina," Revista de estudios regionales, 68 (2003), 89-128; Jesús Valdaliso, "La competitividad internacional de las empresas españolas y sus factores condicionantes," Revista de Historia Industrial, 26 (2004), 13-53; Juan José Durán Herrera, "Empresa multinacional e inversión directa española en el exterior," Universia Business Review, 3 (2004), 114-123; Javier Santiso, "La transformación empresarial de España," Política Exterior, 115 (2007), 1-16. The study by José Ignacio Galán Zazo and Javier González Benito, "Factores explicativos de la inversión directa española en el exterior," Información Comercial Española, 794 (2001), 103-122, analyzes the expansion of Spanish firms using John Dunning's framework.

${ }^{16}$ Gabriela Martínez, Latin American Telecommunications: Telefónica's Conquest (Lanham, 2008); Fernando Gallardo, "Spanish Telecoms in Latin America: Telefónica," in Félix E. Martín and Pablo Toral, Latin America's Quest for Globalization: The Role of Spanish Firms (Ashgate, 2005), 186-204.
} 


\section{Methodology and Sources}

We analyze the way by which Chile's main telecommunications company related to other sectors of the economy by conducting a historical network analysis. Scholars have pointed out this methodology as the best one to "understand how individuals, organizational units, and firms are embedded within relational networks that facilitate the flow of communications, interactions, material transactions, ideas through the social order [and provides us with tools to use archival material to identify] relational ties that link elements of a given structure together." ${ }^{17}$ In more general terms, an analysis of interlocking of boards can provide us with a good picture of how firms adapt to different environments and who the main decision-makers of a particular economy are. ${ }^{18}$ It also permits us to calculate several measures that indicate different types of relationship between the telecommunications company and other economic sectors. The first one we take into consideration is the board of directors' degree centrality. This is the number of boards in other firms to which a particular board of directors (in this case the telecommunications firm) is connected. Knowing the number of connections is not enough, however. Some connections are better than others, so we complement the firm's degree centrality with the betweennness centrality measure. The latter indicates to what degree existing networks provide the firm paths of communication with other firms and facilitates the flow of information across other boards. In this way, a high degree of betweenness, means that the firm's board is a broker (meaning, plays an intermediary role) in the corporate world and therefore can have a significant control over the flow of information between industries and firms. ${ }^{19}$ Finally, we use the eigenvector measure, which indicates

\footnotetext{
${ }^{17}$ Marc J. Ventresca and John W. Mohr, “Archival Research Methods,” in Joel A. C. Baum (ed.), The Blackwell Companion to Organizations (New York, 2002), 818-819.

${ }^{18}$ Jay Lorsch, Pawns and Potentates: The Reality of America's Corporate Boards (Boston, 1989); Michael Useem, The Inner Circle: Large Corporations and the Rise of Political Activity in the US and the UK (Oxford, 1984). Recent studies on the United States and Argentina show that in recent decades the importance of board of directors interlocking has decreased. See, Andrea Lluch and Erica Salvaj, “A longitudinal study of interlocking directories in Argentina and foreign firms' integration into the local capitalism (1923-2000)" in Thomas David and Gerarda Westerhuis (eds.), The power of corporate networks: A comparative and historical perspective (Routledge, forthcoming); Todd Schifeling and Mark Mizruchi, "The Decline of the American Corporate Network, 1960-2010" in Thomas David and Gerarda Westerhuis (eds.), The power of corporate networks: A comparative and historical perspective (Routledge, forthcoming);; Johan Chu, "Who Killed the Inner Circle? The End of the Era of the Corporate Interlock Network" (May 16, 2012) (http://ssrn.com/abstract=2061113 or http://dx.doi.org/10.2139/ssrn.2061113, accessed January 2013). For the Chilean case, however, these networks have remained important. See, Erica Salvaj, "Cohesión y Homogeneidad. Evolución de la red de directorios de las grandes empresas en Chile, 1969-2005” In Eugenio Tironi and José Ossandón (eds.), Adaptación, la empresa chilena después de Friedman (Santiago, 2013).

19 Mark Mizruchi, "What do interlocks do? An Analysis, Critique, and Assessment of Research on Interlocking Directorates," Annual Review of Sociology, 22 (1996), 271-98; Pamela Haunschild and Christine Beckman, "When do interlocks matter? Alternate sources of information and interlock influence," Administrative Science Quarterly, 43, No. 4 (1998), 815-844; Gerald Davis, “The Significance of Board Interlocks for Corporate Governance," Corporate Governance 4,
} 
the degree by which the board of the firm we are studying is connected to other boards that are also central. In other words, this measure indicates to us the firm's status within the network and whether or not the firm belongs to the core of the network ${ }^{20}$. A board that is connected to several boards that are well-connected ones will have a high eigenvector measure.

In order to analyze the relationship between the telecommunications firm and the rest of the economy, we built a database composed by Chile's largest firms in terms of assets and sales for the period we study. The sample includes 165 for 1969, 151 for 1978, 185 for 1988, 244 for 1999, and 250 for 2005. We constructed our sample in the following way: for 1969, we used the ranking of Chile's largest firms published in the book El libro de las 91 published in 1972. ${ }^{21}$ This book was published by the Chilean government during the government of Salvador Allende and aimed to determine which were the largest monopolistic firms in that country. Given the book's political bias we triangulated its information with a ranking we built using the corporations with the highest value in terms of trade of stocks made at the Santiago stock exchange market. Our comparison showed strong consistency in terms of ranking of the Chilean corporations between the information provided by El libro de las 91 and the operations in the stock market. From the ninety-one corporations ranked by El libro de las 91, we found information on board composition for sixty-three of them, which are the ones we use in our study. In addition, our 1969 sample includes the ten largest Chilean state-owned enterprises and the twentyfive largest financial institutions as ranked by Ricardo Behren Fuchs. ${ }^{22}$ Behren Fuchs also built a ranking for 1977, which we used as a proxy for our 1978 calculations. We chose the rest of the firms for 1988, 1999, and 2005 using the unpublished ranking of Chilean firms according to sales as calculated by Chile's revenue office (Servicio de Impuestos Internos). ${ }^{23}$

We gathered information for each one of the boards of these firms, which permits us to build the network. This means that our database contains a picture of all the networks existing within most of the

No. 3 (1996), 154-159; Gerald Davis and Henrich Greve, "Corporate elite network and governance changes in the 1980s," American Journal of Sociology, 103, No. 1 (1997), 1-37; Gerard Sanders and Anja Tuschke, "The adoption of institutionally contested organizational practices: the emergence of stock option pay in Germany," Academy of Management Journal, 50, No. 1 (2007), 33-56.

${ }^{20}$ The literature defines "component" as the main group of firms connected with each other. If there are multiple components, the firms with the greatest eigenvector centrality will be in the larger component (and others might have eigenvector centralities close to zero).

${ }^{21}$ Movimiento de Acción Popular, El libro de las 91: las empresas monopólicas y el area social de la economía chilena (Santiago, 1972).

${ }^{22}$ Roberto Behren Fuchs, "Los bancos e instituciones financieras en la historia económica de Chile. 1811-1983," (PhD Diss. Pontificia Universidad Católica de Chile).

${ }^{23}$ Chile, Servicio de Impuestos Internos, "Ficha Estadística Codificada Uniforme: Estados Financieros de las Empresas." Unpublished database. 
main firms in Chile's corporate sector for the three decades we analyze. In order to determine which particular directors were more influential and why the firm could have chosen them we conducted a detailed biographical research for each one of the directors of the telecommunication firms for all the years we study. When analysing the director's biography we took into consideration their educational background, the types of industries in which they had worked, their political affiliation, and their family origin. We calculate our networks using the UCINET software. ${ }^{24}$

We obtained the information on board composition from Chile's main government regulator agencies (Superintendencia de Bancos e Instituciones Financieras and the Superintendencia de Valores $y$ Seguros) and a large number of corporate annual reports. ${ }^{25}$ The information on the biographies of particular directors was gathered from a wide variety of sources. ${ }^{26}$

\footnotetext{
${ }^{24}$ Stephen Borgatti, Martin Everett, and Linton Freeman, Ucinet for Windows: Software for Social Network Analysis (Cambridge, 2002)

${ }^{25}$ We use the Memoria Anual (annual report) for various years published by the following firms: Agencia Graham, Aguas Décima, Aguas del Valle, Almendral, Automovilísmo y Turismo, Banco Continental, Banco de Chile, Banco de Créditos e Inversiones, Banco del Estado de Chile, Banco Santander, Banmédica, Banvida, Bicecorp, CCU, Celulosa Arauco y Constitución, Cementos Bío Bío, Cementos Polpaico, Cencosud, Chilena Consolidada Seguros de Vida, Clínica las Condes, CN Life Compañía de Seguros, Codelco, Colbún, Compañía Chilena de Fósforos, Compañía Chilena de Navegación Interoceánica, Compañía de Seguros de Vida Consorcio, Compañía de Seguros Francisco de Aguirre, Compañía de Seguros Generales Consorcio, Compañía de Telecomunicaciones de Chile, Compañía de Teléfonos de Chile -ITT, Compañía General de Electricidad, Compañía Industrial el Volcán, Copec, Corpesca, ElectroAndina, Embotelladora Andina, Embotelladoras Chilenas Unidas, Empresa de Transportes de Pasajeros Metro, Empresa Eléctrica Pangue, Empresa Eléctrica Pilmaiquen, Empresa Electrónica Nacional, Empresa Minera de Mantos Blancos, Empresa Nacional de Electricidad, Empresa Nacional de Telecomunicaciones, Empresa Nacional del Carbón, Empresa Periodística de la Nación, Empresa Pesquera Eperva, Empresas CMPC, Entel PCS, Entel Personal, Esval, Falabella, Forestal Arauco, Forestal Copihue, Grupo Security, Holding Gildemeister, Iansa, Industria de Conjuntos Mecánicos Aconcagua, Industria Nacional de Rayón, Industria Nacional del Cemento, Inversiones y Rentas, ISE Seguros de Vida, ISE Seguros Generales, Líneas Aéreas Nacionales (LAN), LQ Inversiones, Minera Valparaíso, P\& S Consorcio, Pacífico V Región, Pesquera Iquique Guanaye, Pesquera Iquique Guanaye, Phillips Chilena, Plásticos Nacionales, Sipsa, Sociedad Agrícola La Rosa Sofruco, Sociedad Austral de Electricidad, Sociedad Austral de Electricidad, Sociedad Concesionaria Rutas del Pacífico, Sociedad Punta del Cobre, Sodimac, Soquimich, Tejidos Caupolicán, Telefónica Larga Distancia, Telefónica Móviles de Chile, Viña San Pedro, Viña Santa Rita.

${ }^{26}$ These sources include (besides the Memorias mentioned in the previous footnote): Enrique Bernstein, Recuerdos de un diplomático: de la Unidad Popular al Gobierno Militar (Santiago, 1993), 54; Salvatore Bizzarro, Historical Dictionary of Chile (Lanham, 2005); Marcelo Bucheli, 'Multinational Corporations, Business Groups, and Economic Nationalism: Standard Oil (New Jersey), Royal Dutch-Shell, and Energy Politics in Chile, 1913-2005', Enterprise and Society, 11, No. 2 (2010), 350-399; Chile, Biblioteca del Congreso, Diccionario biográfico chileno (http: //biografias.ben.cl accessed August 2012); Fernando Campos Harriet, Chile: desarollo educacional, 1810-1960 (Santiago, 1960), 164; Sofía Correa Sutil, Con las riendas del poder: la derecha chilena en el siglo XX (Santiago, 2011); El Mercurio (Santiago) (various years); Brenda Elsey, Citizens and Sportsmen: Fútbol and Politics in Twentieth Century Chile (Austin, 2011), p. 111; Empresa Periodística de Chile, Diccionario biográfico de Chile (Santiago, various years); Hugo Fazio, Mapa actual de la extrema riqueza en Chile (Santiago, 1997), 300; Arturo Fontaine Aldunate, Los economistas y el presidente Pinochet (Santiago, 1988), 78; Cristián Gazmurri, Historia de Chile, 1891-1994 (Santiago, 2012), 477; Genealogías de Chile (http://www.genealog.cl accessed August 2012; International Telecommunication Union (ITU), World Telecommunication Day (Geneva, 1970); Guillermo Lagos Carmona, Historia de las Fronteras de Chile (Santiago, 1966), 61; José Manteola, Guía de la administración pública de Chile y de los principals organismos del sector privado, 1966-1967 (Santiago, 1966); Thomas O'Brien, The Revolutionary Mission: American Enterprise in Latin America, 1900-1945 (Cambridge, 1996), 200; Arturo Olavarría, Chile entre dos Alessandri (Santiago, 1962); Jody Pavilak, Mining for the Nation: The Politics of Chile's Coal Communities from the Popular Front to the Cold War (University Park, 2011), 342; Augusto Salinas, Un pastor Santo (Santiago, 1981), 295; David
} 


\section{Public Utilities Firms and Politics in Latin American History}

Historically, public utilities firms in Latin America have been both a political tool and a target in political debates. Since the late nineteenth century, Latin American modernization-obsessed and foreign markets-oriented rulers were aware that no economic development and international competitiveness was possible without basic infrastructure like railways, roads, ports, telecommunications, or water and sewage. As a result, many rulers created favorable conditions to attract foreign public utility firms under the belief that no domestic corporations or governments had the capital and know-how to quickly build and efficiently run these badly needed services.

The economic and political environment changed after the Great Depression affecting the operations of foreign firms in the utilities sector. During the 1930s, industries in foreign hands witnessed the rise of radical nationalist labor activism while foreign ownership of crucial industries came under attack from different fronts. In the 1930s, some countries engaged in major expropriations of foreign property in a process that peaked in the 1960s and 1970s, particularly in the natural resource sector. In the public utility sector, some governments purchased foreign property or created partnerships rather than operating through concessions. This process was reversed in the 1990s, after an out-ofcontrol foreign debt and problems of hyperinflation in the 1980s pressured governments to privatize state-owned utilities companies and sell them to both domestic and foreign investors, including new ones coming from Spain. ${ }^{27}$

The transition from ISI to an open market economy model also came together with important political changes: during the 1970s most Latin American countries were ruled by military regimes, but by the 1990 s they had been replaced by elected civilian ones. ${ }^{28}$ During the abovementioned political and economic changes, the three main actors owning the Latin American public utilities firms were the domestic state, domestic corporations (often belonging to large conglomerates), and foreign multinationals.

\section{Public Utilities and Chilean Politics}

\footnotetext{
Vásquez and René Jáuregui, El comercio en la memoria y en el futuro de Chile (Santiago, 2008); “Ocho sociedades con cuñas en diez poderosos bancos,' Vistazo 569 (1963), 11; Zeitlin, et al. 'New Princes'

${ }^{27}$ Guillén, Spanish Multinationals.

${ }^{28}$ For a detailed explanation of these long-term processes see, Victor Bulmer-Thomas, An Economic History of Latin America Since Independence (Cambridge, 2003); Samuel Huntington, The Third Way (Tulsa, 1991) Jones, Multinationals.
} 
Chile is a textbook example of the wider processes taking place globally. Between the 1930s and the late 1970s, Chile was a model for countries adopting ISI and its business groups partnered with the government in the implementation of ISI in a process that also included foreign multinationals. ${ }^{29}$ In the 1980s, however, Chile became an open market beacon that pioneered neo-liberal policies later adopted in the other countries in the world. These economic changes took place parallel to equally radical political ones. Between 1932 and 1973, Chile was considered Latin America's most stable democracy. The election of Marxist President Salvador Allende in 1970 led to a great political polarization in the country that culminated in the Pinochet-led 1973 military coup. Pinochet's regime lasted until 1989, when the General lost a plebiscite in which the Chilean people decided whether he should remain in power or whether the country should go back to elected civilian rule. Having changed the political constitution in 1980, Pinochet remained as a senator-for-life and the armed forces kept special privileges. Between 1989 and 2010, Chile was ruled by the center-left political coalition (known as the Concertación) that kept the general framework of the Pinochet-era economic model. ${ }^{30}$

Chile's telecommunications sector mirrors the country's general economic stages. Between 1927 and 1972, the US multinational corporation International Telephone and Telegraph (ITT) controlled most of Chile's telecommunications through its subsidiary the Compañía de Teléfonos de Chile (CTC). In 1971, the Allende government took over ITT-CTC. Allende's actions were facilitated by the fact that in 1972, a series of ITT internal memos and letters showed that ITT was conspiring with the CIA to overthrow Allende. The Christian Democratic Party and Allende's Socialist Party had already criticized ITT before Allende took power because of the deficient and expensive service provided by CTC and the political composition of its board. ${ }^{31}$

Despite the fact that Pinochet's coup was (among other things) an attempt to stop Allende's program of statization of the economy, government ownership actually increased after Pinochet's coup. In 1974, CORFO acquired ITT's shares in CTC (80\% of the total). In 1987, however, CORFO announced that it would gradually reduce its ownership in the company and sell its shares as part of the process of privatization of private utilities. The process concluded in 1989, when the Australian firm Bond Corporation acquired CORFO's remaining shares. That year CTC approved an additional capital

\footnotetext{
${ }^{29}$ Dahse, Mapa; Schneider, Business Politics; Bucheli, "Multinational Corporations."

${ }^{30}$ For a good general work on Chile's transitions, see Luis Corvalán Marquéz, Del anticapitalismo al neoliberalismo en Chile: izquierda, centro y derecha en la lucha entre los proyectos globales, 1950-2000 (Santiago, 2001).

${ }^{31}$ Marcelo Bucheli and Erica Salvaj, 'Multinational Corporation's Obsolescing Legitimacy: ITT in Chile, 1920-1972, Business History Review (forthcoming, Spring 2014).
} 
increase, which led to a 50\% Bond ownership. In 1990, Spain's Telefónica Internacional acquired Bond's shares and changed the company's name to Telefónica Chile CTC. After this acquisition, Telefónica Internacional controlled Chile's domestic and international phone calls markets. ${ }^{32}$

The Chilean state was present in the telecommunications sector before 1972. In 1964, the Chilean government created the state-owned enterprise Entel to cover phone service in isolated regions. The government privatized Entel between 1986 and 1992. Entel's first owners were Italian investors, but the firm eventually fell in hands of Chilean business groups.

\section{Network Calculations of the Chilean Telecommunications Sector}

We conducted our network calculations and built the ego networks for CTC and ENTEL for the years $1969,1978,1988,1999$, and 2005. The ego networks consist of a focal node ("ego") and the nodes this ego is directly connected ("alters") to, plus the ties among the alters (if any). We analyzed the ties of each firm that had at least one director in common with another firm. We assume that the larger the number of directors shared between firms, the stronger the link between those firms. Our results are displayed in Table 1.

\section{[INSERT TABLE 1 AROUND HERE]}

The first period we study is the one prior 1972, when Chile was ruled by a democratic regime and the US multinational ITT owned CTC. During those years, the telecommunications firm played an important role in the Chilean corporate network. Its betweeness centrality number of 6.172 put CTC as the fifth most central firm in that country (see Table 1). This made of CTC one of the brokers of the network. Similarly, the eigenvector centrality value of 18.759 puts it among the top twenty firms with more status in the corporate network and the degree centrality shows it was among the top fifteen most central firms. At least thirty-eight per cent of its directors sat on the board of another firm and these directors provided CTC with very good connections by providing the firm with relations with twentytwo firms in fourteen industries (see Table 1 and Figure 1 with CTC egonetwork). The companies with

\footnotetext{
${ }^{32}$ Martínez, Latin American Telecommunications, 69-70; Telefónica CTC (www.Telefónicactcchile.cl accessed March 2, 2009)
} 
which CTC shared more than one director were the state-owned Empresa Nacional de Energía and the privately owned Cementos Bío Bío, a cement corporation closely linked to the government’s ISI project.

\section{[INSERT FIGURE 1 AROUND HERE]}

The state-owned enterprise Entel shows a different pattern for the pre-1972 period, ranking onehundred-and-thirteenth in terms of centrality (Table 2). Entel's egonetwork also shows the few links the firm had at that time.

\section{[INSERT TABLE 2 AROUND HERE]}

[INSERT FIGURE 2 AROUND HERE]

CTC remained under government ownership between 1972 (year in which Allende expropriated ITT) until 1988. This means, the military government did not immediately re-privatized the firm. Our calculations show that during this period CTC decreased both the number of links with other firms or industries as well as the quality of those links, with just six other companies and six other industries connected through the boards. By 1978, the main connection was with the state-owned sugar company Iansa. By 1988 CTC had fallen to the next to last position in terms of centrality of its board in corporate Chile (Table 1 and egonetworks in Figure 3 show that CTC reduced its number of links during the Pinochet regime).

\section{[INSERT FIGURE 3 AROUND HERE]}

In 1978, Entel had climbed to the eleventh position in terms of eigenvector centrality and second in terms of betweenness centrality (or intermediation). The company increased the number of multiple directors, after having twenty seven per cent of multiple directors in 1969 to thirty-six per cent in 1978 (Table 2). Nevertheless, despite this improvement, the company remained with few links with other companies and industries (9 links in total). The enlargement of the firm's network, however, was a 
short-lived. In 1988, with the firm still belonging to the government, it ranked last in corporate Chile in terms of centrality with no links with any other firm (see Figure 4).

\section{[INSERT FIGURE 4 AROUND HERE]}

The fall in number of connections by CTC and Entel followed a general trend in Chile as a whole. Table 3 shows how during Pinochet's government the average degree of centrality for all the firms in our sample decreased, as did Entel and CTC. It is worth highlighting, however, that this trend was stronger among Entel and CTC than among other firms. By 1988, their degree centrality was below the mean (6 links on average, two for CTC, and none for Entel) (see Table 3).

\section{[INSERT TABLE 3 AROUND HERE]}

The privatization of both CTC and Entel during the military regime and the continuation of the economic model by the subsequent post-1990 democratic governments show a new trend in terms of how both firms networked with the rest of the Chilean society. Table 1 shows a clear change for CTC after Spain's Telefónica acquisition, jumping from the fifty-fifth position in terms of betweenness centrality in 1988, to second in 1999, and falling to twenty-seventh in 2005. The number of linked firms and industries also increased, although not to the degree of the ITT years. In 2005, Telefónica's strongest link was with Banco del Estado.a state owned company. Figure 5 displays the egonetworks of Telefónica CTC for 1999 and 2005.

\section{[INSERT FIGURE 5 AROUND HERE]}

Entel also improved its role in the Chilean corporate network after 1990. After having ranked last in 1988, it jumped up to the eleventh position in 1999 and to the number one position in 2005 (See Table 2). This improvement coincided with the increasing share in ownership of the firm by the Chilean business group Hurtado-Fernández, which linked the firm with eighteen firms in 1999 (after having no connections in 1988) and with thirty-eight in 2005. It is worth noting that most of the firms Entel shared more than one director with belonged to the Fernández-Hurtado group, including Almendral (the group's investment firm) and the powerful Consorcio de Seguros Generales and Consorcio de Seguros 
de Vida, two large life insurance corporations. In Figure 6 we show Entel's egonetworks for 1999 and 2005.

\section{[INSERT FIGURE 6 AROUND HERE]}

\section{Network Evolution and Role of Directors in Corporate Strategy}

The results of our network calculations show that the network strategy of the telecommunications firms CTC and Entel varied according to the type of ownership. In this section we analyze the motivations that each one of these firms under different types of ownership might have had in order to choose a particular network strategy. We conduct our analysis by taking a close look at the directors that belonged to more than one board and provided these firms with links to other industries or corporations. We display the general information of these individuals in the Appendix.

The individuals that belonged to other boards during the years in which ITT owned CTC had very influential positions and connections in the Chilean corporate and political world. These were times in which there was a "revolving door" between Chile's corporate sector and the state's economic development agencies. This type of dynamic resulted from the important role the Chilean elite (organized in business groups) played after the 1930s at coordinating its activities with the government during ISI. ${ }^{33}$ Directors like the powerful and highly influential industrialist Walter Müller not only established some of the country's largest firms (such as Copec, a privately-owned oil distribution firm), but also played an important role at the founding and management of Corfo, the Chilean state agency in charge of funding and coordinating ISI. Others, like Tomás Eduardo Rodríguez Brieba had occupied important positions in the Chilean Chamber of Commerce and were powerful businessmen, and someone like Guillermo Correa Fuenzalida gave CTC links with major corporations, the government (as head of Corfo for some time), and the financial sector. ITT-CTC directors sitting in more than one board sat on boards of companies involved in a wide range of industries including finance, textiles, insurance, plastics, cement, and tourism. In terms of political affiliation, most of these directors belonged to the Liberal and Conservative parties, which were declining in popularity and did not rule the country during this period. In fact, politicians of the main parties strongly criticized the political

\footnotetext{
${ }^{33}$ Vittorio Corbo and Patricio Meller, Antecedentes empíricos de los sectores externo e industrial chilenos, 1950-1970 (Santiago, 1978), 6-7; Ibáñez, Herido, 85-95; Bucheli, 'Multinational Corporations', 370-376.
} 
composition of ITT-CTC's board and in the 1960s used this element to propose an expropriation of the firm. ${ }^{34}$ In sum, the links built by ITT-CTC shows that the firm sought to build a network and coordinate its activities with other firms of Chile's private sector and some state owned companies rather than to build legitimacy with the politicians.

CTC's board composition changed during the years of state ownership under the dictatorship, with more directors connected to the government, state owned companies and less of them connected to other firms or industries (Appendix). We find a similar behavior in Entel for this period. The presence of multiple directors in this firm under the dictatorship can only be justified by the need of a state-owned firm to have individuals overseeing the firm's activities, but not necessarily coordinating with other nonstate firms. A closer look to CTC and Entel's board composition in this period shows that most of the links they had were with state-owned corporations and most of these links are generated through executives working at Corfo, such as Gastón Valdivia Sotto, Corfo's finance manager, who sat on the board of several firms with some degree of state ownership. By 1978, despite the fact that Pinochet's privatization process had already started the Chilean state still owned a significant number of corporations, which meant board members appointed by the government generated many links among corporations.

The type of network strategy followed by CTC and Entel during the Pinochet years can be explained by the general characteristics of the military regime, as a solid and hierarchical one with its authority increasingly concentrated in the hands of General Pinochet. An admirer of Diego Portales, a Chilean nineteenth century dictator who led a process of national unification and pacification through extreme power centralization around the government in the capital city of Santiago and the armed forces, Pinochet once famously said that "there is no a leaf in Chile that stirs without me knowing it.",35 Beyond what could be dismissed as simple megalomaniac rhetoric, evidence by previous studies shows how after taking power, Pinochet developed a series of policies oriented towards decreasing the power of potential competing powers such as the business groups, political parties, organized labor, and even other members of the military junta. ${ }^{36}$ Scholars studying Pinochet's relations with the Chilean elite argue that the general sought to debilitate them to avoid them having the power to conspire against him in the

\footnotetext{
${ }^{34}$ Bucheli and Salvaj, "Multinational Corporation's Obsolescing Legitimacy." The presence of government officials among multiple directors resulted from regulations that required ITT-CTC to have at least two government appointed directors.

${ }^{35}$ Nick Caistor, Chile: A Guide to the People, Politics, and Culture (New York, 2002), 29.

${ }^{36}$ Stefan de Vylder, 'Chile, 1973-1987: los vaivenes de un modelo,' in Roberto García (ed.), Economía y política durante el gobierno militar de Chile (Mexico City, 1989), 55-100; Verónica Valdivia, El golpe después del golpe (Santiago, 2003); Loveman, Chile, 261-307.
} 
future. ${ }^{37}$ Our calculations show that Pinochet succeeded at fragmenting the Chilean elite by decreasing the links at the corporate level between its members. Under those circumstances, the best links a company could have were through informal connections with Pinochet or his inner circle, rather than with other Chilean firms. In addition, the opening of the economy led by Pinochet in the late 1970s and early 1980s obliged many business groups to reorient their activities towards the foreign sector decreasing the usefulness of their internal networks. ${ }^{38}$ The trend was not unique to the telecommunications sector. As we show in Table 3, most Chilean firms decreased their links with each other during the Pinochet years.

CTC's board composition after Telefónica's acquisition in 1990 shows a new type of strategy by the Spanish firm that differed from that followed by ITT or the Chilean government. Telefónica entered Chile right after the end of the Pinochet era and the beginning of a period in which the country was ruled by a center-left coalition known as the Concertación (1990-2011). A close look at CTC's composition under Telefónica shows that the firm did not simply try to create links with Chile's corporate sector, but also with the new ruling political parties. This was apparent by the appointment of directors closely connected to the Concertación, some of them with very strong left-wing credentials. In 1991, Telefónica Internacional appointed Oscar Garretón, its first left-wing director. Garretón’s résumé was clearly different from what the Chilean business elite had been used to. He had been Allende's under-secretary of economy (1970-1972) and member of the parliament for the Socialist Party in 1973, right before the coup. Moreover, during the Allende administration Garretón was in charge of the expropriation of private property and was one of the founding fathers of the political group MAPU (Unitary People's Action Movement), a group of leftist Christian Democrats who decided to excise from their party and join Allende's UP. ${ }^{39}$ Before the coup, Garretón unsuccessfully tried to convince some sailors to mutiny against their superiors to abort the possibility of a military coup. ${ }^{40}$ With this background, Pinochet's Chile was not a safe place for Garretón: soon after the coup Garretón appeared in the pages of $E l$ Mercurio, Chile's main newspaper, as one of the ten "most wanted" criminals. ${ }^{41}$ Garretón escaped Chile

\footnotetext{
${ }^{37}$ Eduardo Silva, 'Business Elites, the State, and Economic Change in Chile', in Silvya Maxfield and Ben R. Schneider (eds.), Business and the State in Developing Countries (Ithaca, 1997), 152-188

${ }^{38}$ Silva, 'Business Elites'.

${ }^{39}$ Simon Collier and William Sater, A History of Chile (Cambridge, 2004), 325. The acronym MAPU has another symbolism. In the language of the Mapuches, one of Chile's indigenous peoples the word "mapu" means "land."

${ }^{40}$ Edward Boorstein, Allende's Chile: An Inside View (New York, 1977), 227; “The end of Allende," The Economist, 3 July 2008.

${ }^{41}$ Mirko Macari, "No todo fue responsabilidad del imperialismo y la derecha: Oscar Guillermo Garretón y su análisis de la oposición a Pinochet," Archivo Chile: Centro de Estudios Miguel Enríquez (2006) (www.archivochile.com accessed October 20, 2009).
} 
and was welcomed in Cuba where he exiled for eight years. Later on, he lived temporarily in Argentina before returning to Chile to join the Socialist Party in $1989 .^{42}$

Given Garretón's past, it is understandable that the Chilean business community was initially shocked after Telefónica appointed him in his board. ${ }^{43}$ Telefónica also appointed individuals close to the Concertación who belonged to the center Christian Democratic Party and had participated in Frei Montalva's government. Between 1991 and 2006, the number of center-left directors in Telefónica CTC's board increased as long as Telefónica's ownership increased as well (Figure 7).

\section{[INSERT FIGURE 7 ABOUT HERE]}

Appointing Concertación directors gave Telefónica political advantages and legitimacy. The firm's control over both the domestic and international phone markets could potentially violate Chile's anti-trust legislation. In 1993, however, after negotiations between Telefónica and the government, Chile's Anti-Trust Commission decreed that the company was not violating the anti-trust law. ${ }^{44}$ The presence of Concertación directors was crucial for this favorable outcome. The closed-door negotiations between the firm and the government took place in Chile's presidential palace in December 1993. The Minister of the Presidency invited representatives of Telefónica and Entel for these talks and the negotiations shifted from being technical to be political. ${ }^{45}$ These negotiations were highly controversial, but Garretón informed the shareholders that the final agreement permitted Telefónica CTC to emerge as a powerful telecommunications company at the international level. ${ }^{46}$

We provide a counter-factual to our previous point by analyzing the period in which Telefónica Internacional did not appoint Concertación directors in Telefónica CTC (1998-2000). During this period, Telefónica Internacional's board had influential members linked to Spain's political right. This change took place after Spain’s right-wing Popular Party took power with José María Aznar in 1996 after a period in which the Socialist Party had ruled the country (1982-1996). Telefónica was a stateowned company by the time Spain transitioned to democracy, but in 1986 the Socialist government sold most of its shares keeping only 20.0 per cent of them. In 1997, Aznar sold the remaining government

\footnotetext{
42 "Profile-International Business-Leftist Turned Capitalist Leads Chilean Phone Company," Los Angeles Times, 2 June, 1994 (www.latimes.com accessed October 20, 2009).

${ }^{43}$ Authors' interviews with corporate left-wing directors and senior headhunters who requested anonymity, Santiago 2008.

${ }^{44}$ Telefónica CTC, Memoria Anual (1993), 9.

${ }^{45}$ Covarrubias, Un cable, 152.

${ }^{46}$ Telefónica CTC, Memoria Anual (1994), 7.
} 
shares turning the firm into a completely private corporation. ${ }^{47}$ In 1999 , the Chilean government considered a new regulatory framework for the telecommunications industry, which meant lower phone rates. Telefónica negotiated with the government but focused on purely technical issues while neglecting political ones. ${ }^{48}$ The government ignored Telefónica's arguments and approved the new phone rate system, which led Telefónica CTC go from a $\$ 290$ million profit in 1999 to a $\$ 95,626$ million loss in $2000 .^{49}$

The 2000 losses forced Telefónica to change its strategy and re-approach the left by appointing Concertación connected directors. ${ }^{50}$ In 2001, they appointed Fernando Bustamante, a former union leader and member of the Socialist Party who was Chile's State Petroleum Company's (ENAP) general manager during Allende and was later imprisoned and tortured under Pinochet. ${ }^{51}$ Bustamante provided CTC with links with the state owned company Metro in the transportation industry, but his political role clearly shows that he also played a role at providing Telefónica's actions with legitimacy (Appendix). He was also a personal friend and adviser of Chilean president Ricardo Lagos and a director at Banco del Estado (a state-owned bank) in representation of the workers. ${ }^{52}$ During this period, CTC had links with several state-owned enterprises due to the presence of directors close to the Concertación coalition.

Negotiating a restructuring that implied layoffs and more flexible job contracts faced initial resistance from the unions. The process was not an easy one for the company or President Lagos, who was directly involved in this process. By June 2001, the workers went on a 26-day strike in which there were violent clashes with the police. ${ }^{53}$ With a member of the Socialist Party Bustamante on board, President Lagos decided not to support the unions in this negotiation, leaving the unions without an important bargaining card. ${ }^{54}$ In the end, Bustamante's strong political influence in the government and understanding of the labor movement permitted an effective resolution in which the unions eventually accepted a personnel reduction of around 4,000 employees.

\footnotetext{
${ }^{47}$ Martínez, Latin American Telecommunications, 8-9; Telefónica, “About Telefónica,” www.Telefónica.es accessed March $2,2009$.

${ }^{48}$ Authors' interviews with corporate directors, Santiago 2008.

${ }^{49}$ Telefónica, Memoria Anual 1999, 7; Covarrubias, Un cable, 166-167.

50 "Sorpresas en elección de nuevo directorio de Telefónica CTC," El Mercurio, 27 April, 2001 (www.emol.com accessed October 31, 2009).

51 "Los nombres del estado: árbol genealógico de las empresas públicas," El Mercurio (Santiago), 15 Oct., 2000 (www.emol.com accessed January 12, 2009); "Fernando Bustamante: presidente del Metro y su rol en el conflicto del transporte," La Tercera (Santiago), 18 Aug. 2002 (www.quepasa.cl accessed February 20, 2009).

52 'Nuevo directorio de Banco Estado', El Mercurio, 28 September, 2001 (www.emol.com accessed October 31, 2009).

${ }^{53}$ Martínez, Latin American Telecommunications, 70.

54 'Paros y amenazas tensan las relaciones en Telefonica CTC', El Mercurio, 6 June, 2001; 'Philippi empezó a cambiar números de Telefónica', El Mercurio, 9 June, 2001; (www.emol.com accessed October 31, 2009).
} 
Figures 8 shows the evolution of the company's profitability during that period, with a strong recovery after 2001. Similarly to what happened with the negotiations around anti-trust issues, the center-left directors legitimized the company's operations before the labor unions.

\section{[INSERT FIGURE 8 ABOUT HERE]}

When appointing their directors, the Chilean business groups had motivations different from those of the Spanish investors. After acquiring Entel in 1990, the Hurtado-Fernández business group appointed a board that gave the firm strong links with a wide range of industries and firms, but minimal links to the government. In fact, after the return of democracy to Chile, most firms belonging to Chilean business groups remained with boards solidly composed by people related to the political right and the corporate world. ${ }^{55}$ Most of Entel's directors present in other boards were at boards that were also part of the Hurtado-Fernández business group, meaning that the group's main motivation was to coordinate activities within the group, while building contacts with the government at the informal level (Tables 1, 2, and 3, and Appendix).

\section{Conclusion}

This paper conducted a network analysis to compare the business strategic and political motivations state-owned enterprises, domestic business groups, and multinational corporations have when deciding the composition of the board of directors in a public utility company in a developing country. We study the case of the Chilean telecommunications sector between 1958 and 2001, because that country provides us with a useful comparative framework consisting of two types of political regimes (authoritarian and democratic), two economic models (ISI protectionism and open market), and three types of ownership in this sector (American multinationals, Spanish multinationals, Chilean business groups, and the Chilean state). During the period we study, Chile was also a country that went through a process of urbanization and creation of a large middle and urban working class in which reliable and affordable telephone services became a necessity for most of the population.

\footnotetext{
${ }^{55}$ Marcelo Bucheli and Erica Salvaj, 'Corporate Political Activity of Multinationals from Newly Developed Countries in Emerging Economies: Spanish Multinational Corporations in Chile, 1990-2005.' Paper presented at the Academy of International Business, Rio de Janeiro (Brazil) June 2010.
} 
Our analysis shows different types of strategies followed by the main owners of the telecommunications industry. While the pre-1972 American owners of ITT sought to build networks with other major Chilean firms, the 1972-1990s Chilean state-owned firms during the military regime showed little interest in seeking out other firms, the post-1990 Spanish investors of Telefónica created a board with close links with the new democratic government, and the post-1990 Chilean owners only built networks within their own group. We show that these different strategies responded to the different motivations each one of these actors had. The American investors wanted to coordinate their activities with other domestic firms and a close relationship with the private financial sector. This came at the cost of neglecting political connections. During the dictatorship, state-owned enterprises did not really need to coordinate their activities with the private sector. Similarly, during this period the strong political concentration of power in the person of Augusto Pinochet demotivated private firms in general to establish networks with each other, when informal connections with Pinochet could suffice. This underscores the importance of the nature of the political regime in corporate strategy. The Spanish investors of Telefónica brought to Chile a model they had already used in Spain for years and sought political legitimacy to its operations by approaching the center-left ruling coalition. This strategy bore benefits to Telefónica when negotiating with the government or the unions. Finally, the board composition chosen by the Chilean business group shows that their main motivation was to keep a close coordination of the telecommunications firm with the other members of the conglomerate.

The second global economy has been dominated by political and economic transitions as well by the presence of state-owned enterprises, business groups, and multinationals of non-traditional capital exporting countries. These actors will continue to play a major role in a world in which recent years have shown an unprecedented enlargement of a middle class demanding affordable and good quality public utility services. We hope that our study can provide some lights on how to analyze the operations of states and firms in this new reality. 
Table 1: Chile. CTC. Descriptive measures, 1969-2005

\begin{tabular}{|c|c|c|c|c|c|}
\hline \multicolumn{6}{|c|}{ CTC } \\
\hline & 1969 & 1978 & 1988 & 1999 & 2005 \\
\hline $\begin{array}{l}\text { Number of companies in } \\
\text { the network: firms used to } \\
\text { build CTC's ego network }\end{array}$ & 165 & 151 & 185 & 244 & 250 \\
\hline $\begin{array}{l}\text { CTC's ranking in terms of } \\
\text { centrality }\end{array}$ & 15 & 10 & 21 & 22 & 25 \\
\hline CTC's centrality value & 24 & 7 & 2 & 11 & 9 \\
\hline $\begin{array}{l}\text { CTC's ranking in terms of } \\
\text { eigenvector }\end{array}$ & 20 & 26 & $\begin{array}{r}\text { Third one } \\
\text { from below }\end{array}$ & 26 & 140 \\
\hline $\begin{array}{l}\text { CTC's Eigenvector } \\
\text { centrality value }\end{array}$ & 18.759 & 0.886 & 0.001 & 1.849 & 0.173 \\
\hline $\begin{array}{l}\text { CTC's ranking in terms of } \\
\text { betweenness centrality }\end{array}$ & 5 & 28 & 55 & 2 & 27 \\
\hline $\begin{array}{l}\text { CTC's betweenness } \\
\text { centrality value }\end{array}$ & 6.172 & 1.868 & 0.279 & 5.323 & 2.283 \\
\hline Type of ownership & $\begin{array}{r}\text { ITT (United } \\
\text { States) } \\
\end{array}$ & Chilean state & $\begin{array}{r}\text { Chilean state } \\
\text { and Bond } \\
\text { (Australia) }\end{array}$ & $\begin{array}{r}\text { Telefónica } \\
\text { (Spain) }\end{array}$ & Telefónica (Spain) \\
\hline Number of directors & 16 & 5 & 8 & 8 & 7 \\
\hline $\begin{array}{l}\text { Percentage of CTC's } \\
\text { directors sitting in boards } \\
\text { of other firms }\end{array}$ & $38 \%$ & $80 \%$ & $38 \%$ & $75 \%$ & $43 \%$ \\
\hline $\begin{array}{l}\text { Number of firms with } \\
\text { which CTC shares } \\
\text { directors }\end{array}$ & 22 & 6 & 2 & 11 & 9 \\
\hline $\begin{array}{l}\text { Firms with which CTC } \\
\text { shares more than one } \\
\text { director }\end{array}$ & $\begin{array}{r}\text { Empresa Nacional } \\
\text { de Electricidad } \\
\text { (Chilean state- } \\
\text { owned enterprise). } \\
\text { Cementos Bio- } \\
\text { Bio (Chilean } \\
\text { private } \\
\text { corporation) }\end{array}$ & $\begin{array}{r}\text { Iansa } \\
\text { (Chilean } \\
\text { state-owned } \\
\text { enterprise })\end{array}$ & - & $\begin{array}{r}\text { Telefónica } \\
\text { (long distance) }\end{array}$ & $\begin{array}{r}\text { Banco del Estado de } \\
\text { Chile }\end{array}$ \\
\hline $\begin{array}{l}\text { Number of industries } \\
\text { linked to CTC through } \\
\text { shared directors }\end{array}$ & 14 & 6 & 1 & 8 & 9 \\
\hline
\end{tabular}

Table 2: ENTEL - Descriptive measures

\begin{tabular}{|l|r|r|r|r|r|}
\hline \multicolumn{7}{|c|}{ ENTEL } \\
\hline $\begin{array}{l}\text { Number of companies in } \\
\text { the network: firms used } \\
\text { to build ENTEL's ego } \\
\text { network }\end{array}$ & $\mathbf{1 9 6 9}$ & $\mathbf{1 9 7 8}$ & $\mathbf{1 9 8 8}$ & $\mathbf{1 9 9 9}$ & $\mathbf{2 0 0 5}$ \\
\hline $\begin{array}{l}\text { ENTEL's ranking in } \\
\text { terms of centrality }\end{array}$ & 165 & 151 & 185 & 244 & 250 \\
\hline ENTEL's centrality value & 36 & 8 & $\begin{array}{r}\text { Last one. No } \\
\text { links }\end{array}$ & 11 & 1 \\
\hline
\end{tabular}




\begin{tabular}{|c|c|c|c|c|c|}
\hline $\begin{array}{l}\text { ENTEL's ranking in } \\
\text { terms of eigenvector }\end{array}$ & 113 & 11 & $\begin{array}{r}\text { Last one. No } \\
\text { links }\end{array}$ & 31 & 3 \\
\hline $\begin{array}{l}\text { ENTEL'S eigenvector } \\
\text { centrality } \\
\text { value }\end{array}$ & 1.309 & 11.843 & 0 & \multirow[t]{2}{*}{0.648} & 43.098 \\
\hline $\begin{array}{l}\text { ENTEL's ranking in } \\
\text { terms of betweenness } \\
\text { centrality }\end{array}$ & 78 & 2 & $\begin{array}{r}\text { Last one. No } \\
\text { links } \\
\end{array}$ & & 3 \\
\hline $\begin{array}{l}\text { ENTEL's betweenness } \\
\text { centrality value }\end{array}$ & 0.329 & 8.186 & 0 & 3.917 & 5.286 \\
\hline Type of ownership & Chilean state & Chilean state & Chilean state & $\begin{array}{r}\text { Stet (Telecom } \\
\text { Italia) joint } \\
\text { with the } \\
\text { Hurtado/Ferná } \\
\text { ndez } \\
\text { conglomerate } \\
\text { (Chilean } \\
\text { business group) }\end{array}$ & $\begin{array}{r}\text { Hurtado/Fernánde } \\
\mathrm{z} \text { conglomerate }\end{array}$ \\
\hline Number of directors & 11 & 11 & 7 & 9 & 8 \\
\hline $\begin{array}{l}\text { Percentage of ENTEL's } \\
\text { directors sitting in boards } \\
\text { of other firms }\end{array}$ & $27 \%$ & $36 \%$ & $0 \%$ & $67 \%$ & $78 \%$ \\
\hline $\begin{array}{l}\text { Number of firms with } \\
\text { which ENTEL shares } \\
\text { directors }\end{array}$ & 3 & 9 & 0 & 18 & 38 \\
\hline $\begin{array}{l}\text { Firms with which } \\
\text { ENTEL shares more than } \\
\text { one director }\end{array}$ & $\begin{array}{r}\text { Empresa } \\
\text { Nacional de } \\
\text { Electricidad } \\
\text { (Chilean state- } \\
\text { owned } \\
\text { enterprise) }\end{array}$ & - & - & $\begin{array}{r}\text { P\&S, } \\
\text { Almendral, } \\
\text { Compañía de } \\
\text { Seguros } \\
\text { Consorcio } \\
\end{array}$ & \begin{tabular}{|r} 
Almendral, \\
Consorcio de \\
Seguros \\
Generales, \\
Consorcio de \\
Seguros De Vida, \\
CN Life \\
Compañía de \\
Seguros
\end{tabular} \\
\hline $\begin{array}{l}\text { Number of industries } \\
\text { linked to ENTEL } \\
\text { through shared directors }\end{array}$ & 3 & 7 & 0 & 12 & 13 \\
\hline
\end{tabular}

Table 3. Chile. Degree centrality for Entel, CTC, and average for Chile's corporate sector, 1969-2005.

\begin{tabular}{|l|r|r|r|r|r|}
\hline & $\mathbf{1 9 6 9}$ & $\mathbf{1 9 7 8}$ & $\mathbf{1 9 8 8}$ & $\mathbf{1 9 9 9}$ & $\mathbf{2 0 0 5}$ \\
\hline Average degree centrality & 13 & 3 & 6 & 8 & 10 \\
\hline Degree Centrality Entel & 4 & 9 & 0 & 22 & 45 \\
\hline Degree Centrality CTC & 24 & 7 & 2 & 11 & 9 \\
\hline
\end{tabular}


Figure 1. ITT-CTC. Ego Network (Interlocking directorates 1969).

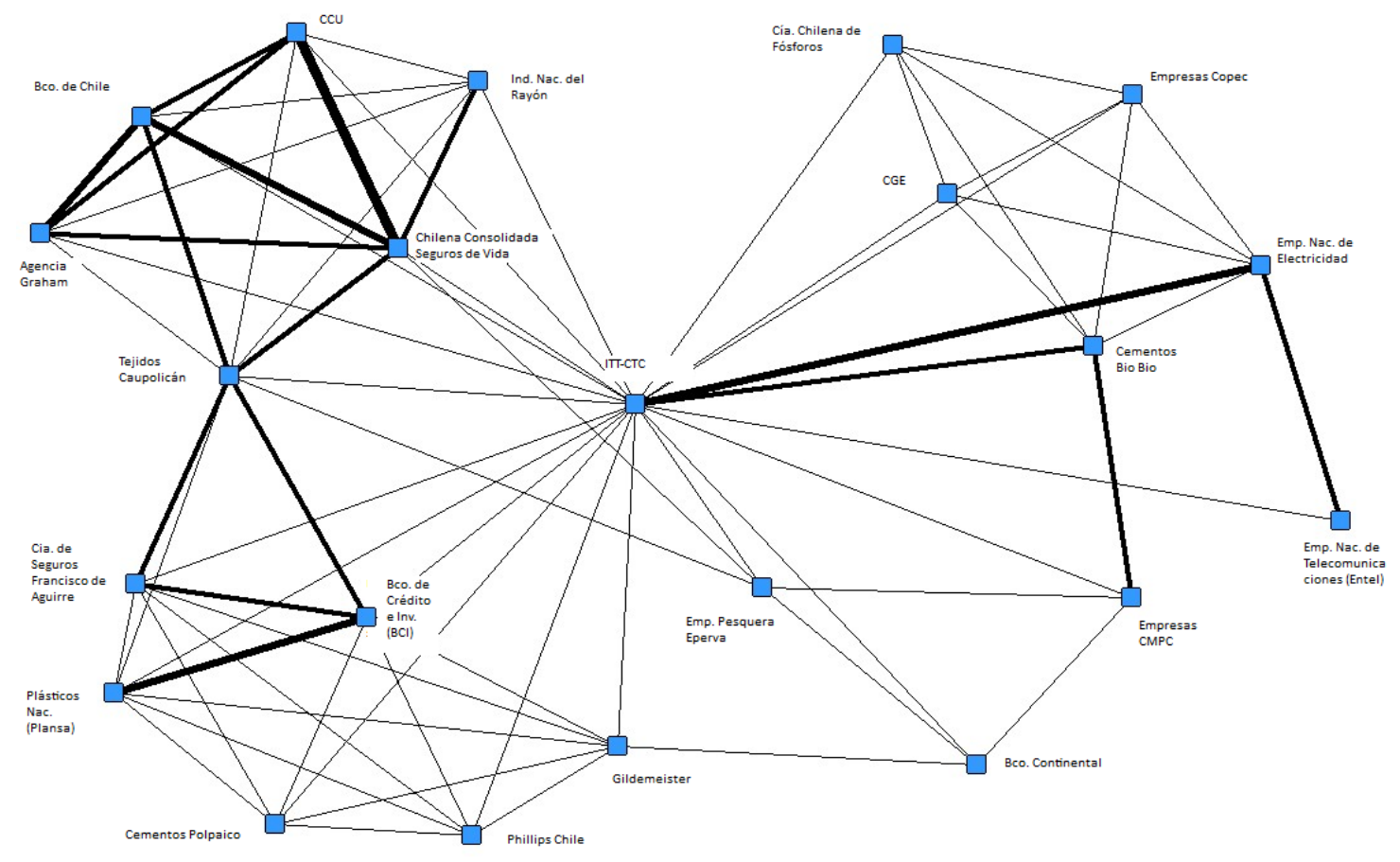


Figure 2. ENTEL. Ego Network (Interlocking directorates 1969).

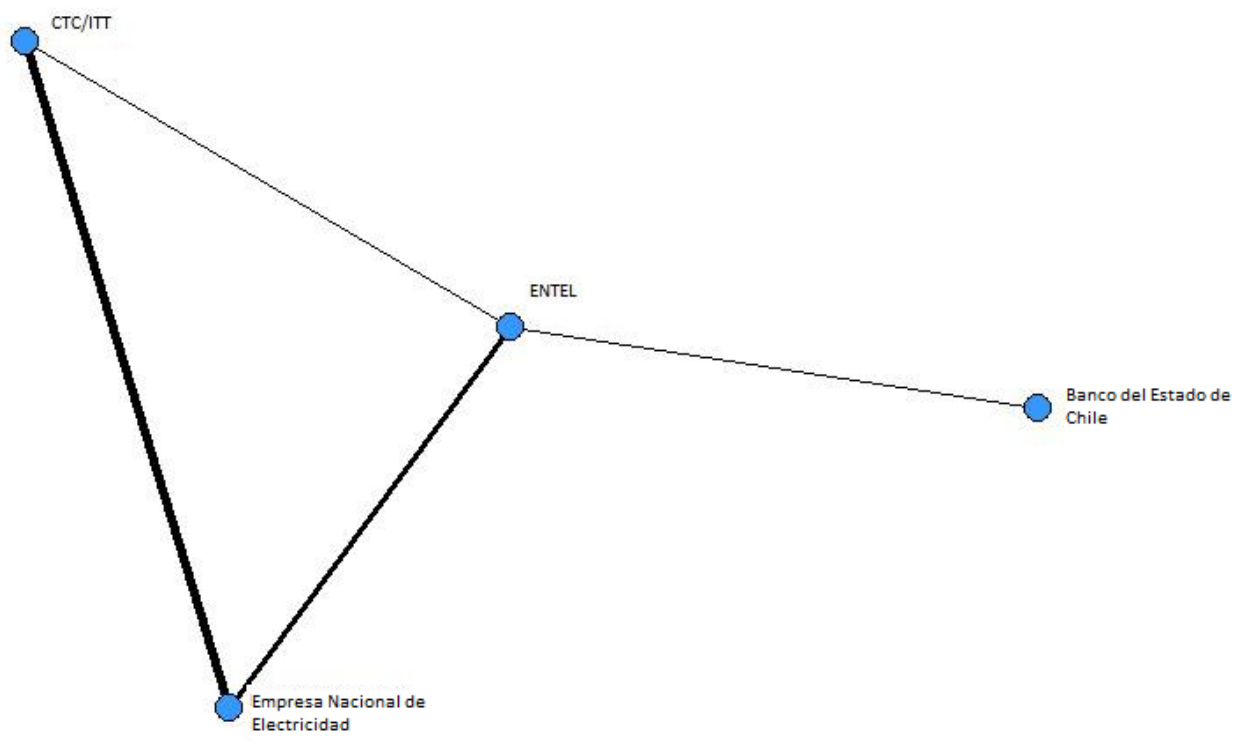


Figure 3. CTC Ego Networks (Interlocking directorates 1978 and 1988) 1978

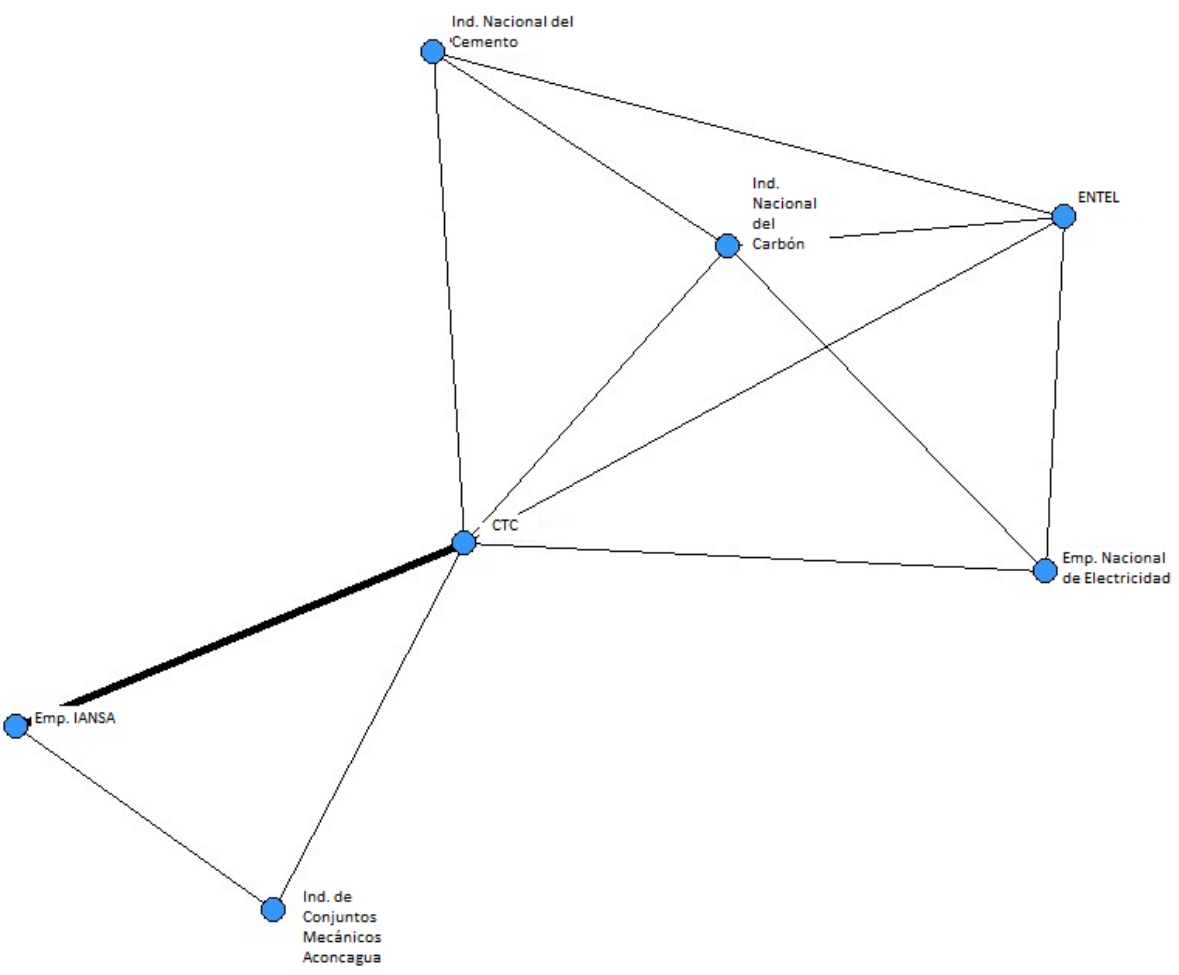

1988

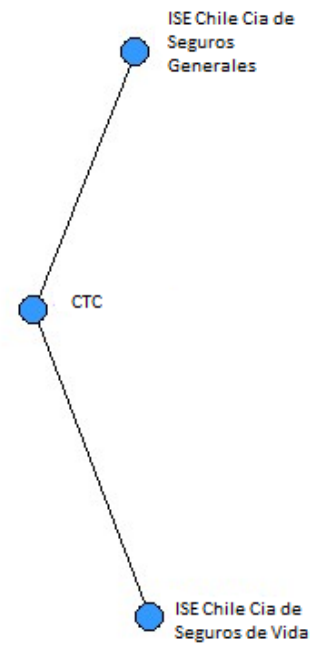


Figure 4. ENTEL. Ego Networks (Interlocking directorates 1978 and 1988)

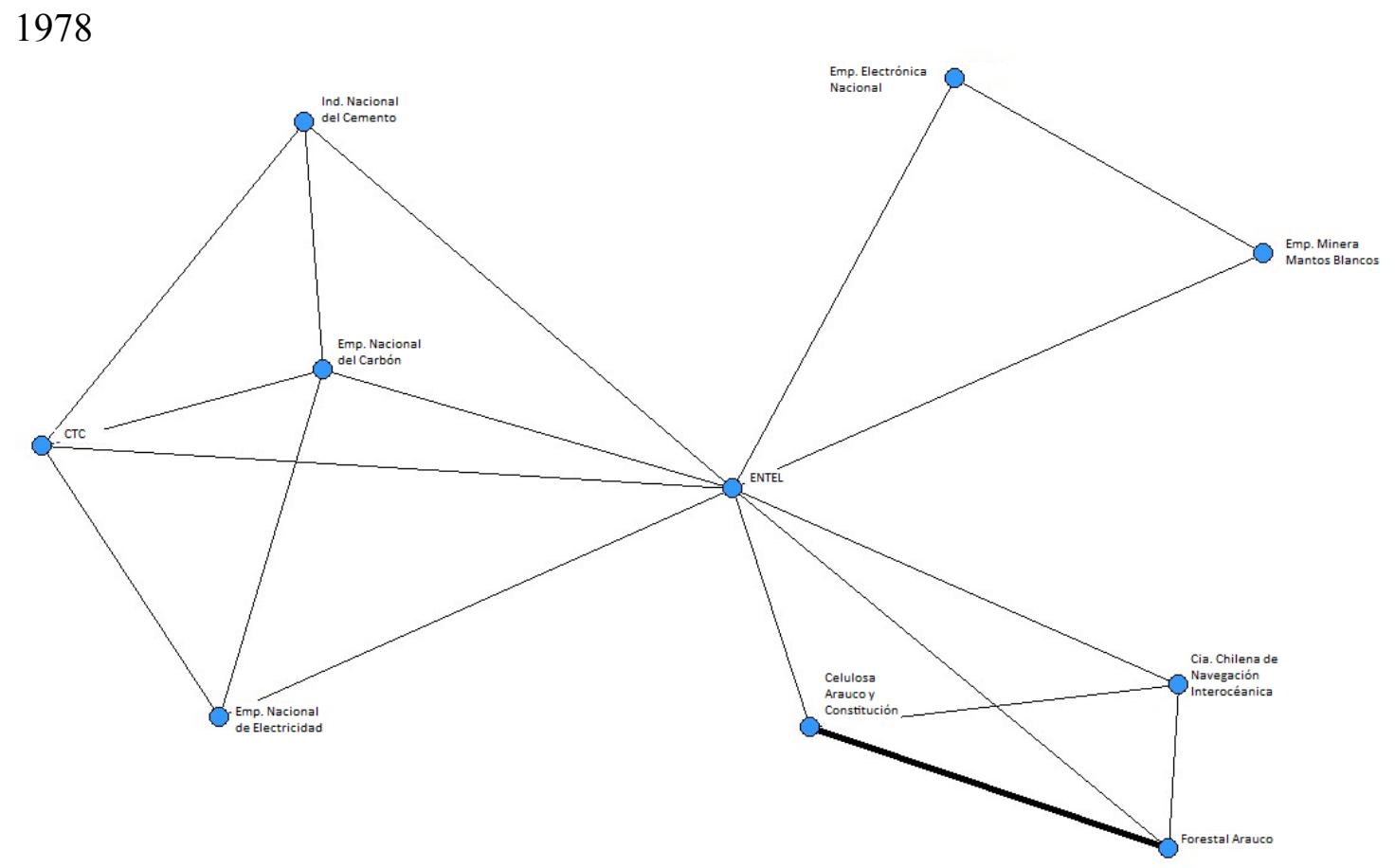

1988

ENTEL 
Figure 5. Telefónica CTC Ego Networks (Interlocking directorates 1999 and 2005) 1999

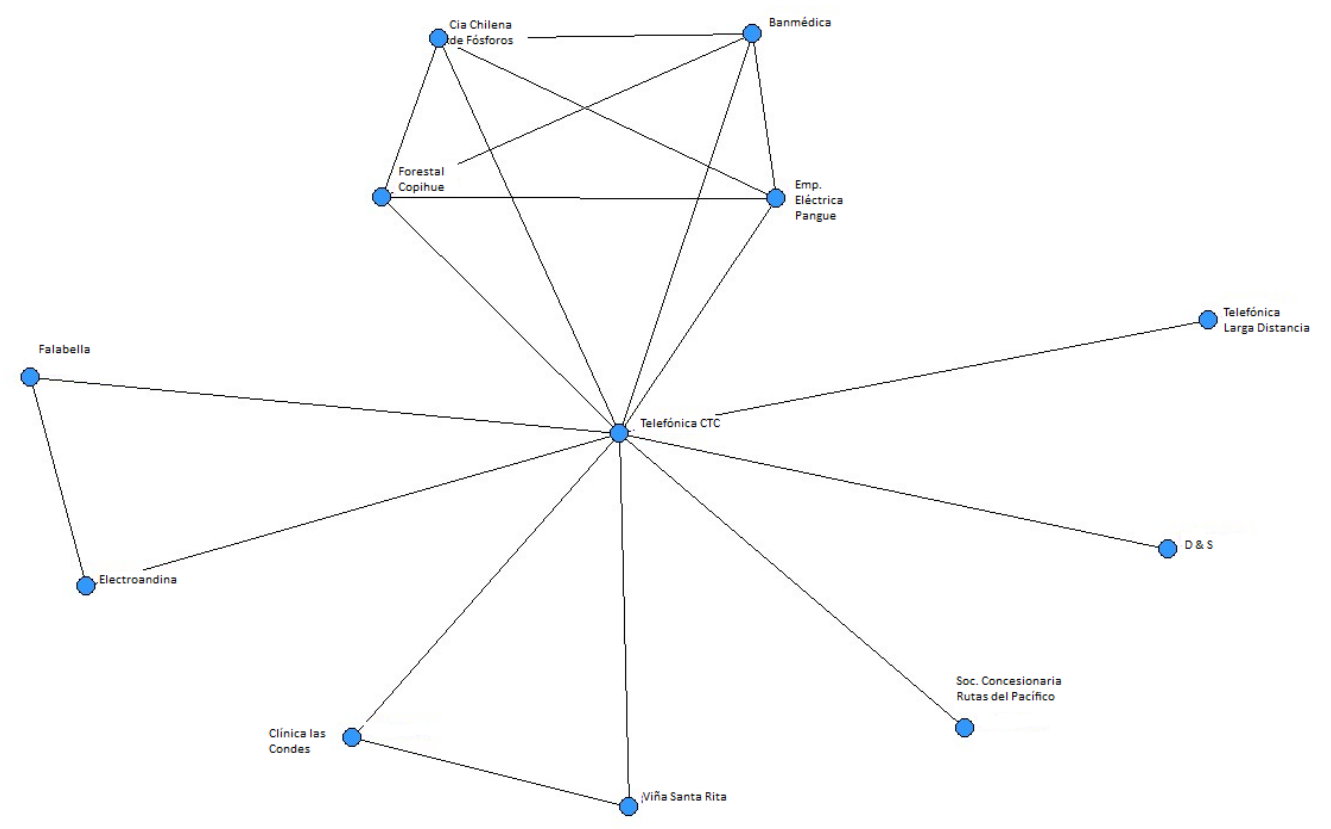

2005

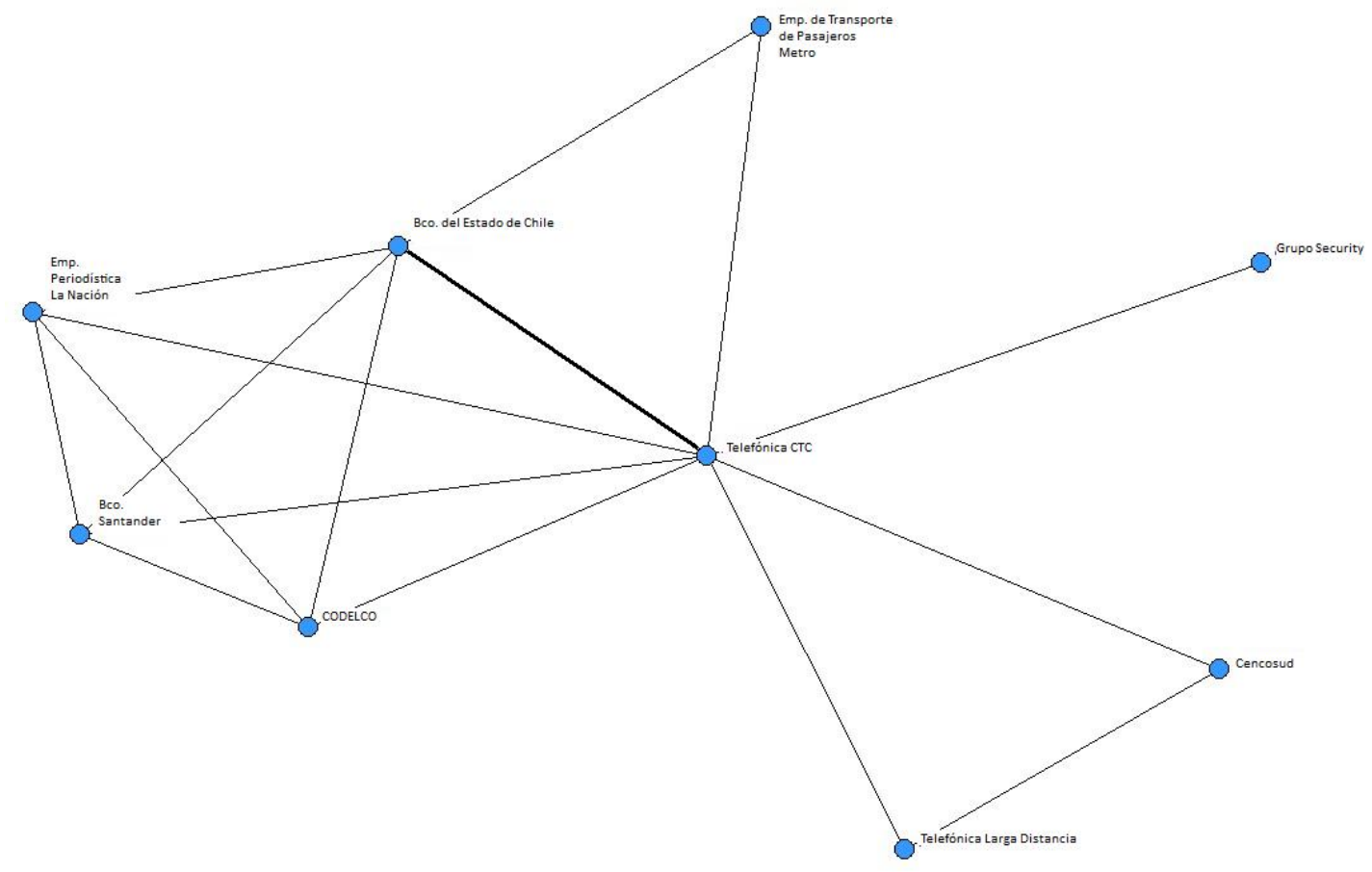


Figure 6. ENTEL. Ego Networks (Interlocking directorates 1999 and 2005) 1999

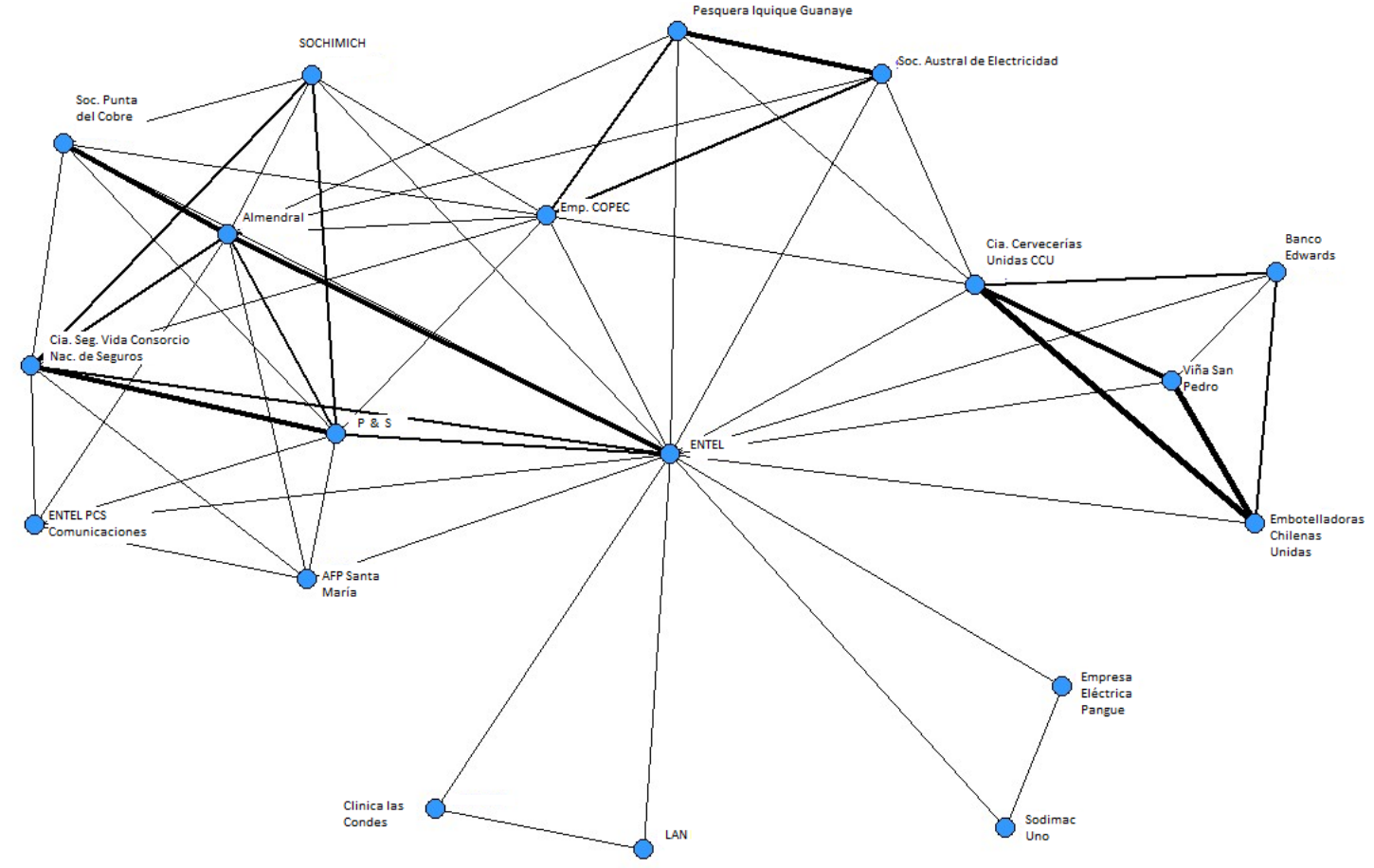

2005

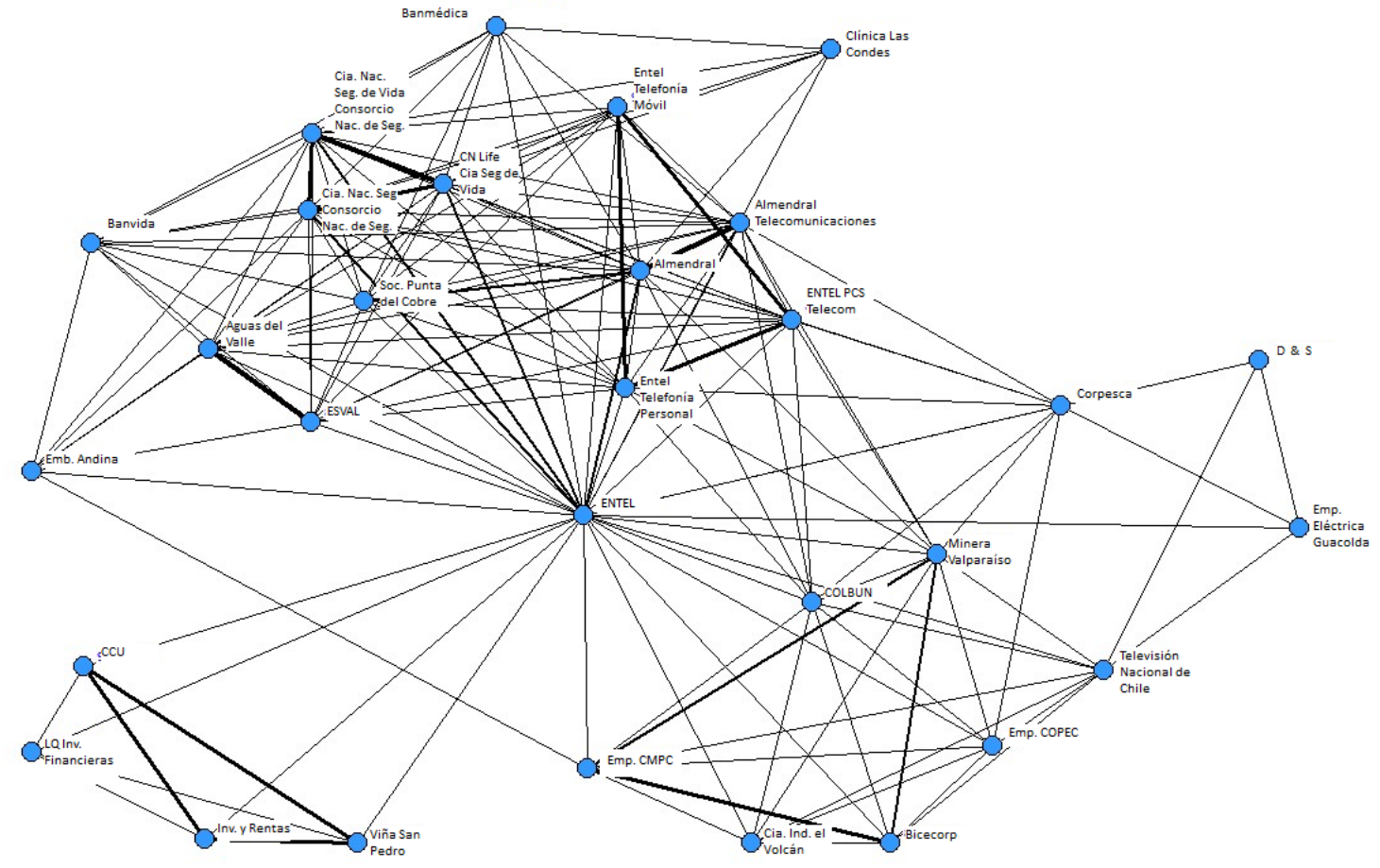


Figure 7: Telefónica de Chile. Board composition and ownership evolution, 1980- 2006

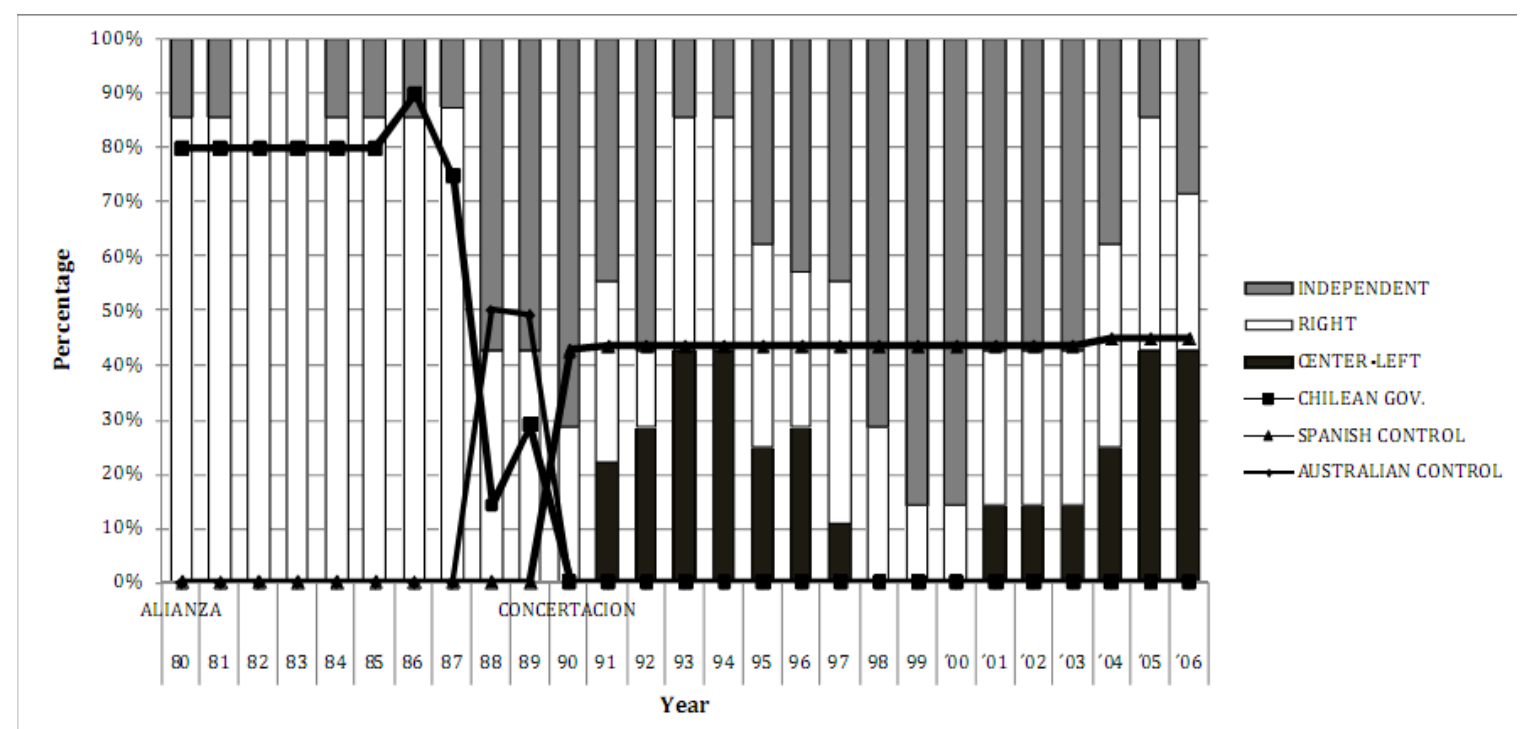

Source: authors' adaptation from Telefónica, Memoria Anual (various years). The vertical bars indicate the political representation of the board in percentages. The lines indicate the ownership of the firm in terms of the nationality of the companies owning Telefónica. 
Figure 8: Telefónica Chile. Profits, 1986-2006 (millions of dollars)

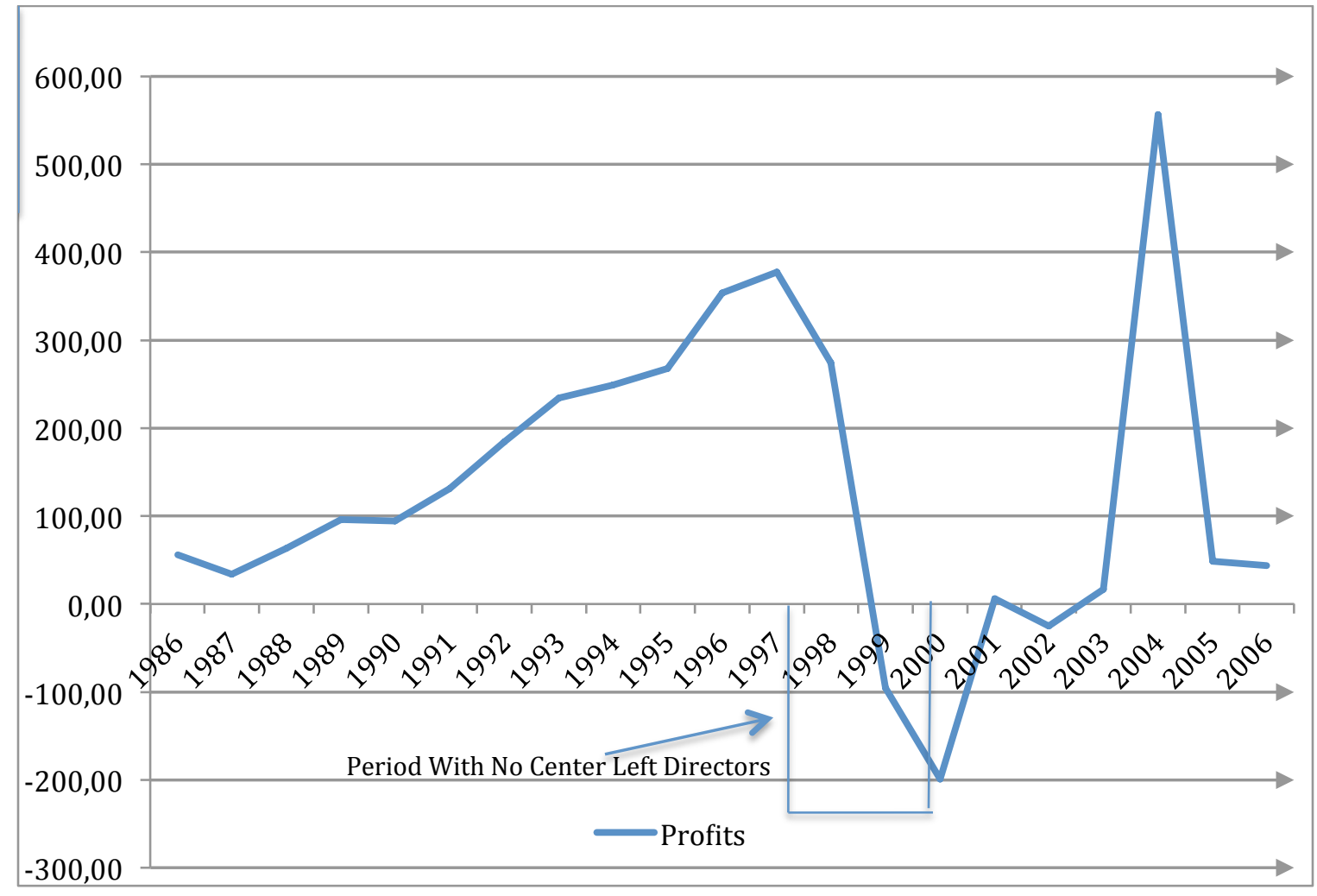

Source: Telefónica, Memoria Anual (various years) 


\section{Appendix: Biographical information of CTC and Entel Multiple Directors}

\begin{tabular}{|c|c|c|c|c|c|}
\hline Year & Firms & $\begin{array}{l}\text { Multiple } \\
\text { directors }\end{array}$ & Firms & Industry & Short Biography \\
\hline 1970 & CTC & $\begin{array}{l}\text { Edgardo Cruz } \\
\text { Plaza }\end{array}$ & $\begin{array}{l}\text { Empresa Nacional de } \\
\text { Electricidad }\end{array}$ & $\begin{array}{l}\text { Telecommunicati } \\
\text { ons and Energy }\end{array}$ & $\begin{array}{l}\text { Superintendent of } \\
\text { Energy and Gas, } \\
\text { government director at } \\
\text { Telefónica }\end{array}$ \\
\hline 1970 & CTC & $\begin{array}{l}\text { Tomás Eduardo } \\
\text { Rodríguez Brieva }\end{array}$ & $\begin{array}{l}\text { Automovilismo y } \\
\text { Turismo, Cementos } \\
\text { Bio Bio }\end{array}$ & $\begin{array}{l}\text { Cement and } \\
\text { Services }\end{array}$ & $\begin{array}{l}\text { Businessman. } \\
\text { President of the } \\
\text { Chamber of } \\
\text { Commerce (1957- } \\
1960)\end{array}$ \\
\hline 1970 & CTC & $\begin{array}{l}\text { Vicente Izquierdo } \\
\text { Besa }\end{array}$ & $\begin{array}{l}\text { Banco Continental, } \\
\text { Empresas CMPC, } \\
\text { Empresa Pesquera } \\
\text { Eperva }\end{array}$ & $\begin{array}{l}\text { Bank, Forestry, } \\
\text { Fishing }\end{array}$ & $\begin{array}{l}\text { Founder and Honorary } \\
\text { President of } \\
\text { Sonapesca. Nephew of } \\
\text { former Chilean } \\
\text { President Arturo } \\
\text { Alessandri Besa }\end{array}$ \\
\hline 1970 & CTC & $\begin{array}{l}\text { Ernesto Barros } \\
\text { Jarpa }\end{array}$ & $\begin{array}{l}\text { Plásticos Nacionales, } \\
\text { Compañía de Seguros } \\
\text { Francisco de Aguirre, } \\
\text { Gildemeister, Phillips } \\
\text { Chilena, Cementos } \\
\text { Polpaico, Banco de } \\
\text { Créditos e } \\
\text { Inversiones }\end{array}$ & $\begin{array}{l}\text { Plastics, } \\
\text { appliances, } \\
\text { insurance, retail, } \\
\text { manufacturing, } \\
\text { banking }\end{array}$ & $\begin{array}{l}\text { Lawyer, Chilean } \\
\text { academic and } \\
\text { politician (Foreign } \\
\text { Minister in 1921,1925 } \\
\text { and 1942). Member of } \\
\text { the Club de la Unión }\end{array}$ \\
\hline 1970 & CTC & $\begin{array}{l}\text { Walter Müller } \\
\text { Hess }\end{array}$ & $\begin{array}{l}\text { Cia. General de } \\
\text { Electricidad, Cia. } \\
\text { Chilena de Fósforos, } \\
\text { Emp. Copec, Emp. } \\
\text { Nac. De Electricidad, } \\
\text { Cementos Bio Bio }\end{array}$ & $\begin{array}{l}\text { Energy, Industry, } \\
\text { Cement, Forestry, } \\
\text { Fuel }\end{array}$ & $\begin{array}{l}\text { Founder of Copec and } \\
\text { relevant role at Corfo }\end{array}$ \\
\hline 1970 & CTC & $\begin{array}{l}\text { Guillermo Correa } \\
\text { Fuenzalida }\end{array}$ & $\begin{array}{l}\text { Industria Nacional de } \\
\text { Rayón, Agencia } \\
\text { Graham, Tejidos } \\
\text { Caupolicán, CCU, } \\
\text { Banco de Chile, } \\
\text { Chilena Consolidada } \\
\text { Seguros de Vida }\end{array}$ & $\begin{array}{l}\text { Textiles, } \\
\text { beverages, } \\
\text { banking, } \\
\text { Insurance }\end{array}$ & $\begin{array}{l}\text { Academic (Professor } \\
\text { of Law), Chilean } \\
\text { politician (Minister of } \\
\text { Education) and } \\
\text { president of the Bank } \\
\text { of Chile. Director of } \\
\text { the Corporación de }\end{array}$ \\
\hline
\end{tabular}




\begin{tabular}{|c|c|c|c|c|c|}
\hline & & & & & $\begin{array}{l}\text { Fomento, Sociedad } \\
\text { Agrícola y Comercial } \\
\text { Colcura S.A., and } \\
\text { Compañía Carbonífera } \\
\text { e Industrial de Lota in } \\
\text { 1948. Partner and head } \\
\text { of the Lawyers } \\
\text { Association and the } \\
\text { National Society of } \\
\text { Agriculture. }\end{array}$ \\
\hline 1970 & CTC & $\begin{array}{l}\text { Santiago Astraín } \\
\text { Castro }\end{array}$ & $\begin{array}{l}\text { Emp. Nacional de } \\
\text { Electricidad }\end{array}$ & Energy & $\begin{array}{l}\text { Academic, pioneer of } \\
\text { satellite technology, } \\
\text { was founder of Entel } \\
\text { Chile and CEO of } \\
\text { Intelsat. He worked in } \\
\text { Corfo, Endesa and } \\
\text { Consejo Nacional de } \\
\text { la Vivienda. } \\
\text { Government director } \\
\text { at CTC. }\end{array}$ \\
\hline 1978 & CTC & Hernán Büchi Buc & Iansa & Sugar & $\begin{array}{l}\text { Chilean politician, } \\
\text { served as Minister of } \\
\text { Finance under } \\
\text { Pinochet. In } 1990 \text { he } \\
\text { founded think-tank } \\
\text { Libertad y Desarrollo. } \\
\text { Professor and } \\
\text { chairman of the board } \\
\text { of Universidad del } \\
\text { Desarrollo. Director at } \\
\text { Lucchetti, Quiñenco, } \\
\text { Madeco, Copesa, } \\
\text { SOQUIMICH, Parque } \\
\text { Arauco, Falabella, and } \\
\text { others. }\end{array}$ \\
\hline 1978 & CTC & $\begin{array}{l}\text { Renato Varela } \\
\text { Correa }\end{array}$ & $\begin{array}{l}\text { Iansa, Industria de } \\
\text { Conjuntos Mecánicos } \\
\text { Aconcagua }\end{array}$ & $\begin{array}{l}\text { Sugar, metal } \\
\text { mechanic }\end{array}$ & President of ENTEL \\
\hline 1978 & CTC & $\begin{array}{l}\text { Gerson Echavarría } \\
\text { Mendoza }\end{array}$ & $\begin{array}{l}\text { Empresa Nacional de } \\
\text { Electricidad }\end{array}$ & Energy & $\begin{array}{l}\text { Lieutenant Colonel, } \\
\text { Chief Executive of } \\
\text { CTC. Undersecretary }\end{array}$ \\
\hline
\end{tabular}




\begin{tabular}{|c|c|c|c|c|c|}
\hline & & & & & $\begin{array}{l}\text { of } \\
\text { Telecommunications } \\
\text { and CEO Cidcom. }\end{array}$ \\
\hline 1978 & $\begin{array}{l}\text { CTC/E } \\
\text { NTEL }\end{array}$ & $\begin{array}{l}\text { Sergio Vial } \\
\text { Faundes }\end{array}$ & $\begin{array}{l}\text { Entel, Empresa } \\
\text { Nacional del Carbón, } \\
\text { Industria Nacional } \\
\text { del Cemento }\end{array}$ & $\begin{array}{l}\text { Telecommunicati } \\
\text { ons, Mining, } \\
\text { Cement }\end{array}$ & $\begin{array}{l}\text { Director of several } \\
\text { companies such as } \\
\text { Carbonifera Schwager } \\
\text { S.A. and Sociedad } \\
\text { Nacional Marítima s.a } \\
\text { - SONAMAR S.A }\end{array}$ \\
\hline 1988 & CTC & $\begin{array}{l}\text { Fernando Lyon } \\
\text { Salcedo }\end{array}$ & Ise Seguros de Vida & Insurance & $\begin{array}{l}\text { Auditor General of the } \\
\text { Army and the military } \\
\text { prosecutor }\end{array}$ \\
\hline 1988 & CTC & $\begin{array}{l}\text { José Martínez } \\
\text { Muñoz }\end{array}$ & $\begin{array}{l}\text { Ise Seguros } \\
\text { Generales }\end{array}$ & Insurance & Lawyer, businessman. \\
\hline 1999 & CTC & $\begin{array}{l}\text { Javier Aguirre } \\
\text { Nogues }\end{array}$ & $\begin{array}{l}\text { Telefónica Larga } \\
\text { Distancia }\end{array}$ & $\begin{array}{l}\text { Telecommunicati } \\
\text { ons }\end{array}$ & $\begin{array}{l}\text { President of CTC and } \\
\text { Valores Bavaria }\end{array}$ \\
\hline 1999 & CTC & $\begin{array}{l}\text { Luis Alfonso Cid } \\
\text { Alonso }\end{array}$ & $\begin{array}{l}\text { Sociedad } \\
\text { Concesionaria Rutas } \\
\text { del Pacífico }\end{array}$ & Infrastructure & $\begin{array}{l}\text { Spanish citizen, } \\
\text { President of Fuerza } \\
\text { Nueva, and } \\
\text { businessman }\end{array}$ \\
\hline 1999 & CTC & $\begin{array}{l}\text { Hans Eben } \\
\text { Oyadenel }\end{array}$ & $D \& S$ & Retail & Vicepresident of D\&S \\
\hline 1999 & CTC & $\begin{array}{l}\text { Nicolás Majluf } \\
\text { Sapag }\end{array}$ & $\begin{array}{l}\text { Falabella, } \\
\text { ElectroAndina }\end{array}$ & Retail, energy & $\begin{array}{l}\text { Engineer, academic, } \\
\text { researcher and } \\
\text { consultant. Chairman } \\
\text { of the state National } \\
\text { Copper Corporation of } \\
\text { Chile (Codelco-Chile). } \\
\text { Director at CCU } \\
\text { (Vice-president), } \\
\text { Multitiendas Corona, } \\
\text { Cecinas San Jorge, } \\
\text { Maderas Chile } \\
\text { (President) }\end{array}$ \\
\hline 1999 & CTC & $\begin{array}{l}\text { Felipe Montt } \\
\text { Fuenzalida }\end{array}$ & $\begin{array}{l}\text { Banmédica, Forestal } \\
\text { Copihue, Emp. } \\
\text { Electrica Pangue, } \\
\text { Compañía Chilena de } \\
\text { Fósforos }\end{array}$ & $\begin{array}{l}\text { Healthcare, } \\
\text { forestry, energy }\end{array}$ & $\begin{array}{l}\text { Director Forestal } \\
\text { Copihue and } \\
\text { Scotiabank. President } \\
\text { at Adich }\end{array}$ \\
\hline
\end{tabular}




\begin{tabular}{|c|c|c|c|c|c|}
\hline 1999 & CTC & $\begin{array}{l}\text { Andrés Navarro } \\
\text { Haeussler }\end{array}$ & $\begin{array}{l}\text { Clínica las Condes, } \\
\text { Viña Santa Rita }\end{array}$ & $\begin{array}{l}\text { Healthcare, } \\
\text { beverages }\end{array}$ & $\begin{array}{l}\text { Businessman, founder } \\
\text { and senior partner of } \\
\text { Sonda. Chairman of } \\
\text { Clínica Las Condes } \\
\text { and director at Salfa } \\
\text { Corp. Shareholder of } \\
\text { AFP Modelo and } \\
\text { Banca Internacional. } \\
\text { Director of } \\
\text { Universidad San } \\
\text { Sebastián }\end{array}$ \\
\hline 2005 & CTC & $\begin{array}{l}\text { Cristian Aninat } \\
\text { Salas }\end{array}$ & $\begin{array}{l}\text { Telefónica Larga } \\
\text { Distancia }\end{array}$ & $\begin{array}{l}\text { Telecommunicati } \\
\text { ons }\end{array}$ & $\begin{array}{l}\text { Fiscal of Telefónica } \\
\text { Chile S.A. Related to } \\
\text { Katalyx and } \\
\text { Telefónica USA }\end{array}$ \\
\hline 2005 & CTC & $\begin{array}{l}\text { Fernando } \\
\text { Bustamante } \\
\text { Huerta }\end{array}$ & $\begin{array}{l}\text { Empresa de } \\
\text { Transporte de } \\
\text { Pasajeros Metro, } \\
\text { Banco del Estado de } \\
\text { Chile }\end{array}$ & Transportation & $\begin{array}{l}\text { Businessman, and } \\
\text { political consultant. } \\
\text { Government officer } \\
\text { during Ricardo Lagos } \\
\text { and Salvador Allende } \\
\text { governments. Director } \\
\text { of Enap and Banco } \\
\text { Estado President of } \\
\text { Metro (Subway) }\end{array}$ \\
\hline 2005 & CTC & $\begin{array}{l}\text { Marco Colodro } \\
\text { Hadjes }\end{array}$ & $\begin{array}{l}\text { Codelco, Banco } \\
\text { Santander, Empresa } \\
\text { Periodística la } \\
\text { Nación, Banco del } \\
\text { Estado de Chile }\end{array}$ & $\begin{array}{l}\text { Mining, Bank, } \\
\text { Media }\end{array}$ & $\begin{array}{l}\text { Close friend of } \\
\text { president Ricardo } \\
\text { Lagos. General } \\
\text { economist at Banco } \\
\text { Central during Allende } \\
\text { Government, director } \\
\text { of Banco Santander. } \\
\text { President of } \\
\text { Telefónica Chile and } \\
\text { director of Codelco. } \\
\text { President of TVN } \\
\text { (Televisión Nacional) }\end{array}$ \\
\hline
\end{tabular}




\begin{tabular}{|c|c|c|c|c|c|}
\hline 2005 & CTC & $\begin{array}{l}\text { Andrés Concha } \\
\text { Rodríguez }\end{array}$ & $\begin{array}{l}\text { Empresa Eléctrica } \\
\text { Pilmaiquen y Grupo } \\
\text { Security }\end{array}$ & $\begin{array}{l}\text { Energy, Insurance } \\
\text { and Bank }\end{array}$ & $\begin{array}{l}\text { Leader of the business } \\
\text { association Sofofa. } \\
\text { General director of } \\
\text { Foreign Economic } \\
\text { Relations. Director of } \\
\text { Telefónica Chile and } \\
\text { Security Group. He } \\
\text { was director of } \\
\text { ProChile and worked } \\
\text { for president Jorge } \\
\text { Alessandri. }\end{array}$ \\
\hline 2005 & CTC & $\begin{array}{l}\text { Alfonso Ferrari } \\
\text { Herrero }\end{array}$ & $\begin{array}{l}\text { Telefónica Móviles } \\
\text { de Chile }\end{array}$ & $\begin{array}{l}\text { Telecommunicati } \\
\text { ons }\end{array}$ & $\begin{array}{l}\text { Spaniard. Director at } \\
\text { Telefónica Spain, } \\
\text { executive of Banco } \\
\text { Urquijo, and director } \\
\text { of Sociedad de } \\
\text { Valores }\end{array}$ \\
\hline 2005 & CTC & $\begin{array}{l}\text { Bruno Philippi } \\
\text { Irarrázabal }\end{array}$ & $\begin{array}{l}\text { Telefónica Móviles } \\
\text { de Chile, Cencosud }\end{array}$ & $\begin{array}{l}\text { Telecommunicati } \\
\text { ons and retail }\end{array}$ & $\begin{array}{l}\text { Former Secretary of } \\
\text { the National Energy } \\
\text { Commission, operates } \\
\text { as Chairman of } \\
\text { CHILGENER and } \\
\text { Director Pilmaiquén } \\
\text { Electricity }\end{array}$ \\
\hline 1970 & ENTEL & $\begin{array}{l}\text { Edgardo Cruz } \\
\text { Plaza }\end{array}$ & $\begin{array}{l}\text { CTC/ITT, Emp. } \\
\text { Nacional de } \\
\text { Electricidad }\end{array}$ & $\begin{array}{l}\text { Telecommunicati } \\
\text { ons and energy }\end{array}$ & $\begin{array}{l}\text { Superintendent } \\
\text { SEGTEL }\end{array}$ \\
\hline 1970 & ENTEL & $\begin{array}{l}\text { Patricio Silva } \\
\text { Echenique }\end{array}$ & $\begin{array}{l}\text { Banco del Estado de } \\
\text { Chile }\end{array}$ & Bank & $\begin{array}{l}\text { Economist, diplomat } \\
\text { and Chilean politician. } \\
\text { Member of the } \\
\text { editorial board in El } \\
\text { Pacífico. He was } \\
\text { Undersecretary of } \\
\text { Foreign Affairs and } \\
\text { Director of the } \\
\text { Regional Bureau for } \\
\text { Latin America } \\
\text { Development Program } \\
\text { at United Nations. }\end{array}$ \\
\hline
\end{tabular}




\begin{tabular}{|c|c|c|c|c|c|}
\hline 1970 & ENTEL & $\begin{array}{l}\text { Sergio Molina } \\
\text { Silva }\end{array}$ & $\begin{array}{l}\text { Empresa Nacional de } \\
\text { Electricidad }\end{array}$ & Energy & $\begin{array}{l}\text { Economist, academic, } \\
\text { businessman, and } \\
\text { politician. Director of } \\
\text { the Department of } \\
\text { Communication and } \\
\text { Culture and former } \\
\text { president of the } \\
\text { Central Bank of Chile. } \\
\text { Vice-President of the } \\
\text { Development Bank } \\
\text { and chairman of the } \\
\text { Universidad of Viña } \\
\text { del Mar. }\end{array}$ \\
\hline 1978 & ENTEL & $\begin{array}{l}\text { Carlos Penaglia } \\
\text { Rojas }\end{array}$ & $\begin{array}{l}\text { Empresa Nacional de } \\
\text { Electricidad }\end{array}$ & Energy & Businessman \\
\hline 1978 & ENTEL & $\begin{array}{l}\text { Rolando Ramos } \\
\text { Muñoz }\end{array}$ & $\begin{array}{l}\text { Empresa Minera de } \\
\text { Mantos Blancos, } \\
\text { Empresa Electrónica } \\
\text { Nacional }\end{array}$ & $\begin{array}{l}\text { Mining, } \\
\text { Electronics }\end{array}$ & $\begin{array}{l}\text { Director at Inter- } \\
\text { American } \\
\text { Development Bank, } \\
\text { Minister of Finance, } \\
\text { President of Codelco. } \\
\text { President of CORFO. }\end{array}$ \\
\hline 1978 & ENTEL & $\begin{array}{l}\text { Gastón Valdivia } \\
\text { de la Sotta }\end{array}$ & $\begin{array}{l}\text { Compañía Chilena de } \\
\text { Navegación } \\
\text { Interoceanica, } \\
\text { Celulosa Arauco y } \\
\text { Constitución, } \\
\text { Forestal Arauco }\end{array}$ & $\begin{array}{l}\text { Transportation, } \\
\text { Forestry }\end{array}$ & $\begin{array}{l}\text { Director of Marítima } \\
\text { Lloyd, Manager } \\
\text { Corporación de } \\
\text { Fomento de la } \\
\text { Producción. }\end{array}$ \\
\hline 1999 & ENTEL & $\begin{array}{l}\text { Luis Felipe } \\
\text { Gazitúa Achondo }\end{array}$ & $\begin{array}{l}\text { Almendral, Sociedad } \\
\text { Austral de } \\
\text { Electricidad, } \\
\text { Pesquera Iquique } \\
\text { Guanaye }\end{array}$ & $\begin{array}{l}\text { Fishing, } \\
\text { Investment, } \\
\text { Energy }\end{array}$ & $\begin{array}{l}\text { President of } \\
\text { Asociación Nacional } \\
\text { Automotriz de Chile } \\
\text { AG, director at } \\
\text { Sociedad Austral de } \\
\text { Electricidad, president } \\
\text { of telecommunication } \\
\text { conglomerate } \\
\text { Almendral }\end{array}$ \\
\hline 1999 & ENTEL & $\begin{array}{l}\text { Carlos Hurtado } \\
\text { Ruiz-Tagle }\end{array}$ & $\begin{array}{l}\text { Sodimac, Empresa } \\
\text { Electrica Pangue }\end{array}$ & Retail, Energy & $\begin{array}{l}\text { Economist, } \\
\text { businessman and } \\
\text { politician. Minister } \\
\text { Patricio Aylwin } \\
\text { government. Director }\end{array}$ \\
\hline
\end{tabular}




\begin{tabular}{|c|c|c|c|c|c|}
\hline & & & & & $\begin{array}{l}\text { at Televisión } \\
\text { Nacional. Minister of } \\
\text { Agriculture and } \\
\text { president of } \\
\text { Chilevisión, Entel, } \\
\text { Molymet and (Sofofa). }\end{array}$ \\
\hline 1999 & ENTEL & $\begin{array}{l}\text { Juan Hurtado } \\
\text { Vicuña }\end{array}$ & $\begin{array}{l}\text { Sipsa, Copec, Soc. } \\
\text { Punta del Cobre, } \\
\text { Entel PCS, P\&S, } \\
\text { Soquimich, } \\
\text { Almendral, Pacífico } \\
\text { V Región }\end{array}$ & $\begin{array}{l}\text { Oil, Forestry, } \\
\text { Mining, } \\
\text { Investments, } \\
\text { Retail }\end{array}$ & $\begin{array}{l}\text { Main shareholder of } \\
\text { Hurtado Vicuña } \\
\text { business group (Entel, } \\
\text { Chilquinta). Owner } \\
\text { of Quebrada Blanca, } \\
\text { Pucobre, Colbún, } \\
\text { Banmédica, Esval, } \\
\text { Almacenes Paris and } \\
\text { Empresas Banmédica, } \\
\text { Pacifico V Región. }\end{array}$ \\
\hline 1999 & ENTEL & $\begin{array}{l}\text { Juan José } \\
\text { MacAuliffe } \\
\text { Granello }\end{array}$ & $\begin{array}{l}\text { Almendral, P\&S, } \\
\text { Consorcio }\end{array}$ & $\begin{array}{l} \\
\text { Insurance, } \\
\text { Telecommunicati } \\
\text { ons, Retail }\end{array}$ & $\begin{array}{l}\text { Director of Chilquinta, } \\
\text { COIA, Pesquera } \\
\text { Coloso, CCU, Watts } \\
\text { Alimentos, Almendral, } \\
\text { Cruz Blanca Isapre } \\
\text { and President of Entel } \\
\text { and Aguas Décima. }\end{array}$ \\
\hline 1999 & ENTEL & $\begin{array}{l}\text { Francisco Pérez } \\
\text { MacKenna }\end{array}$ & $\begin{array}{l}\text { CCU, Viña San } \\
\text { Pedro, } \\
\text { Embotelladoras } \\
\text { Chilenas Unidas }\end{array}$ & Beverages & $\begin{array}{l}\text { Member of Centro de } \\
\text { Estudios para el } \\
\text { Desarrollo de la } \\
\text { Empresa. Director of } \\
\text { Madeco, Quiñenco, } \\
\text { Citicorp-Chile, } \\
\text { Cervecerías Unidas } \\
\text { and Bankers trust. }\end{array}$ \\
\hline 1999 & ENTEL & $\begin{array}{l}\text { Sebastián Piñera } \\
\text { Echenique }\end{array}$ & $\begin{array}{l}\text { LAN, Clínica las } \\
\text { Condes }\end{array}$ & $\begin{array}{l}\text { Transportation, } \\
\text { Health }\end{array}$ & $\begin{array}{l}\text { Chilean politician and } \\
\text { businessman. } \\
\text { President of Chile } \\
\text { (2010-present). } \\
\text { Founder of Tolten, } \\
\text { consultant at Banco } \\
\text { Mundial and Inter- } \\
\text { American } \\
\text { Development Bank. } \\
\text { CEO at Banco }\end{array}$ \\
\hline
\end{tabular}




\begin{tabular}{|c|c|c|c|c|c|}
\hline & & & & & $\begin{array}{l}\text { Citicorp, owner and } \\
\text { director at LAN }\end{array}$ \\
\hline 2005 & ENTEL & $\begin{array}{l}\text { René Cortázar } \\
\text { Sánz }\end{array}$ & (1) & $\begin{array}{l}\text { Energy, Retail } \\
\text { and Media }\end{array}$ & $\begin{array}{l}\text { Economist, researcher, } \\
\text { academic and Chilean } \\
\text { politician. Secretary of } \\
\text { State, Minister of } \\
\text { Transport and } \\
\text { Communications and } \\
\text { Minister of Education. } \\
\text { Director at D\&S, } \\
\text { Entel, Corpbanca, } \\
\text { AES-Geneder. } \\
\text { Vicepresident of Icare } \\
\text { and director of Centro } \\
\text { de Estudios Laborales } \\
\text { Alberto Hurtado. } \\
\text { President of the board } \\
\text { of Cepal. }\end{array}$ \\
\hline 2005 & ENTEL & $\begin{array}{l}\text { José Antonio } \\
\text { Garcés Silva }\end{array}$ & $\begin{array}{l}\text { Banvida, } \\
\text { Embotelladora } \\
\text { Andina, Esval, Aguas } \\
\text { del Valle, CN Life, } \\
\text { Compañía de } \\
\text { Seguros, Compañía } \\
\text { de Seguros de Vida } \\
\text { Consorcio }\end{array}$ & $\begin{array}{l} \\
\text { Insurance, } \\
\text { Beverages, } \\
\text { Utilities (Water) }\end{array}$ & $\begin{array}{l}\text { Businessman, } \\
\text { president of bottling } \\
\text { company Andina- } \\
\text { Coca-Cola, founder of } \\
\text { vineyard Garces Silva. } \\
\text { Director at Banvida; } \\
\text { Inmobiliaria FFV, } \\
\text { Fundación Paternitas, } \\
\text { Vina Montes, Viña } \\
\text { Garcés Silva, and } \\
\text { Carnes Nuble. }\end{array}$ \\
\hline 2005 & ENTEL & $\begin{array}{l}\text { Luis Felipe } \\
\text { Gazitúa Achondo }\end{array}$ & $\begin{array}{l}\text { Colbún, Almendral } \\
\text { Telecom, Corpesca, } \\
\text { Entel PCS, Entel } \\
\text { Personal, Pesquera } \\
\text { Iquique Guanaye, } \\
\text { Almendral, Minera } \\
\text { Valparaíso, Aguas } \\
\text { Décima }\end{array}$ & $\begin{array}{l}\text { Energy, } \\
\text { Investments, } \\
\text { Fishing, } \\
\text { Telecommunicati } \\
\text { ons, Mining, } \\
\text { Utilities (Water) }\end{array}$ & $\begin{array}{l}\text { President of } \\
\text { Asociación Nacional } \\
\text { Automotriz de Chile } \\
\text { AG. Director at } \\
\text { Sociedad Austral de } \\
\text { Electricidad, Empresas } \\
\text { Pizarreño, Corpesca } \\
\text { and Colbun }\end{array}$ \\
\hline
\end{tabular}




\begin{tabular}{|c|c|c|c|c|c|}
\hline 2005 & ENTEL & $\begin{array}{l}\text { Juan Hurtado } \\
\text { Vicuña }\end{array}$ & $\begin{array}{l}\text { Pacifico V Region, } \\
\text { Almendral, Aguas } \\
\text { del Valle, Esval, } \\
\text { Entel PCS, Sociedad } \\
\text { Punta del Cobre }\end{array}$ & $\begin{array}{l}\text { Mining, } \\
\text { Investment, } \\
\text { Utilities (Water), } \\
\text { Telecommunicati } \\
\text { ons }\end{array}$ & $\begin{array}{l}\text { Main shareholder of } \\
\text { Hurtado Vicuña } \\
\text { business group (Entel, } \\
\text { Chilquinta). Owner } \\
\text { of Quebrada Blanca, } \\
\text { Pucobre, Colbún, } \\
\text { Banmédica, Esval, } \\
\text { Almacenes Paris and } \\
\text { Empresas Banmédica, } \\
\text { Pacifico V Región. }\end{array}$ \\
\hline 2005 & ENTEL & $\begin{array}{l}\text { Juan José } \\
\text { MacAuliffe } \\
\text { Granello }\end{array}$ & $\begin{array}{l}\text { Banmedica, Clínica } \\
\text { las Condes, } \\
\text { Almendral, CN Life } \\
\text { Cia de Seguros, } \\
\text { Aguas Décima, Cia. } \\
\text { Seg. De Vida } \\
\text { Consorcio, Cia. De } \\
\text { Seg. Generales } \\
\text { Consorcio }\end{array}$ & $\begin{array}{l}\text { Health, } \\
\text { Insurance, } \\
\text { Investments }\end{array}$ & $\begin{array}{l}\text { Director of Chilquinta, } \\
\text { COIA, Pesquera } \\
\text { Coloso, CCU, Watts } \\
\text { Alimentos, Almendral, } \\
\text { Cruz Blanca Isapre } \\
\text { President of Entel and } \\
\text { Aguas Decima. }\end{array}$ \\
\hline 2005 & ENTEL & $\begin{array}{l}\text { Bernardo Matte } \\
\text { Larraín }\end{array}$ & $\begin{array}{l}\text { Colbún, Copec, } \\
\text { Minera Valparaiso, } \\
\text { Cia Industrial el } \\
\text { Volcan, Bicecorp, } \\
\text { Empresas CMPC, } \\
\text { Televisión Nacional } \\
\text { de Chile, Sociedad } \\
\text { Agrícola La Rosa } \\
\text { Sofruco }\end{array}$ & $\begin{array}{l} \\
\text { Energy, Oil, } \\
\text { Forestry, Mining, } \\
\text { Investments, } \\
\text { Media, } \\
\text { Agribusiness }\end{array}$ & $\begin{array}{l}\text { Leader of Centro de } \\
\text { Estudios Públicos and } \\
\text { the Matte Business } \\
\text { Group. Director of } \\
\text { Bolsa de Santiago and } \\
\text { president of Colbún. } \\
\text { Director of Copec, } \\
\text { Bicecorp and Camara } \\
\text { de compensación del } \\
\text { Barrio de C Santiago }\end{array}$ \\
\hline 2005 & ENTEL & $\begin{array}{l}\text { Francisco Pérez } \\
\text { MacKenna }\end{array}$ & $\begin{array}{l}\text { LQ inversiones, Viña } \\
\text { San Pedro, CCU, } \\
\text { Inversiones y Rentas }\end{array}$ & $\begin{array}{l}\text { Investments, } \\
\text { Beverages }\end{array}$ & $\begin{array}{l}\text { Member of Centro de } \\
\text { Estudios para el } \\
\text { Desarrollo de la } \\
\text { Empresa. Director of } \\
\text { Madeco, Quiñenco, } \\
\text { Citicorp-Chile, } \\
\text { Cervecerías Unidas } \\
\text { and Bankers trust. }\end{array}$ \\
\hline 2005 & ENTEL & $\begin{array}{l}\text { Álvaro Correa } \\
\text { Rodríguez }\end{array}$ & Aguas Décima & Utilities (water) & $\begin{array}{l}\text { Director: Entel-Chile, } \\
\text { Compañía Hispano } \\
\text { Americana de } \\
\text { Servicios, Inmobiliaria }\end{array}$ \\
\hline
\end{tabular}




\begin{tabular}{|l|l|l|l|l|}
\hline & & & & Tierra del Sol, \\
& & & & \\
& & & & Gerente general \\
Almendral.
\end{tabular}

